\title{
18. CONSTRAINTS ON THE GEOMETRY AND FRACTURING OF HOLE 894G, HESS DEEP, FROM FORMATION MICROSCANNER LOGGING DATA ${ }^{1}$
}

\author{
Bernard Célérier, ${ }^{2}$ Christopher J. MacLeod, ${ }^{3}$ and Peter K. Harvey ${ }^{4}$
}

\begin{abstract}
Ocean Drilling Program Hole 894G, sited on a small horst within Hess Deep, was drilled in lower oceanic crust that was generated at the East Pacific Rise and then rifted by the propagating Cocos/Nazca divergent plate boundary. Difficult drilling conditions in fractured gabbros resulted in a washed-out hole.

Despite these unfavorable circumstances, open-hole logs from the Formation MicroScanner (FMS) tool string provide strong constraints on the fracture orientations and suggest a few directions of preferential enlargement. These results were obtained because five logging passes were recorded to compensate for the expected low data quality by redundancy and because the now classical analysis of FMS data has been adapted to this situation of multiple passes and washed out borehole.

An east enlargement direction is thought to be related to the east-west strike of the dense network of fractures observed both in cores and on the FMS resistivity images, and an east-northeast enlargement direction may be the result of drill pipe wear along the borehole plunge direction. Additional east-southeast to south-southeast and north-northeast enlargements may reflect the influence of either the Nazca-Galapagos or the Cocos-Nazca plate boundary state of stress, respectively. However, the interpretation of these poorly defined directions remains uncertain.

The analysis of the FMS resistivity images shows mainly east-west striking and southward dipping fractures and very few north-south trending features. This suggests a strong Cocos-Nazca control on brittle deformation in the Hess Deep. The distribution of orientation of the fractures identified on the FMS images is very similar to that obtained from core veins reoriented relative to paleomagnetic north. Matching the two sets requires that the remanent magnetization direction points north-northwest. The preferred interpretation of this result is a vertical-axis component of tectonic rotation of $30^{\circ}$ to $40^{\circ}$ counterclockwise.
\end{abstract}

\section{INTRODUCTION}

\section{Logging for Tectonics in Hess Deep}

Hess Deep is an intraoceanic rift located between the East Pacific Rise and the western tip of the Cocos Nazca spreading propagator. The rift exhumed deep levels of oceanic lithosphere generated at the East Pacific Rise and make it one of the rare places where the lower oceanic crust and uppermost mantle of a fast spreading ridge are exposed (Fig. 1) (Searle and Francheteau, 1986; Lonsdale, 1988; Searle, 1989; Francheteau et al., 1990). ODP Leg 147 drilled such rocks for the first time (ODP Leg 147 Shipboard Scientific Party, 1993; Mével et al., 1993).

The drilled formations are expected to display structures relating both to the early north-south-trending East Pacific Rise accretion and the later east-west-trending rifting. An extensive study of fractures within the core was undertaken on board (Shipboard Scientific Party, 1993c) but the orientation of these data is critical to a better understanding of the tectonics of Hess Deep, its relationship to hydrothermal processes, and, in particular, which of the north-south-trending

'Mével, C., Gillis, K.M., Allan, J.F., and Meyer, P.S. (Eds.), 1996. Proc. ODP. Sci. Results, 147: College Station, TX (Ocean Drilling Program).

${ }^{2}$ Université de Montpellier II - CNRS, URA 1767, Case courrier 57, 34095 Montpellier Cedex 5, France. bernard@dstu.univ-montp2.fr

${ }^{3}$ Department of Earth Sciences, University of Wales College of Cardiff, P.O. Box 914, Cardiff CF1 3YE, United Kingdom. Formerly at: Institute of Oceanographic Sciences, Brook Road, Wormley, Surrey GU8 5UB, United Kingdom; and Borehole Research, Department of Geology, University of Leicester, Leicester LE1 7RH, United Kingdom. macleod@cardiff.ac.uk

${ }^{4}$ Borehole Research, Department of Geology, University of Leicester, Leicester LE1 7RH, United Kingdom. pkh@leicester.ac.uk
East Pacific Rise or east-west-trending Cocos-Nazca rift exerted the greater influence on brittle tectonics and hence fracture permeability.

There are four ways to gather oriented data from an ODP borehole: the first one is to reorient the core pieces by using the direction of the remanent magnetization (e.g., Cannat and Pariso, 1991; Shipboard Scientific Party, 1992a, 1992b), the second one involves reorienting the core piece by matching it with the corresponding oriented borehole images provided by the Formation MicroScanner (FMS; see Table 1 for full description of acronyms and abbreviations) or the Borehole Televiewer (BHTV) (Shipboard Scientific Party, 1985; Newmark et al., 1985a; Kessels and Kück, 1992; MacLeod et al., $1992,1994)$, the third one is to directly obtain an oriented core using a core scriber device, but this is unreliable and expensive thus rarely done, and the fourth one is to directly pick the feature on the oriented FMS or BHTV images (Ekstrom et al., 1987; Pezard and Luthi, 1988; Héliot et al., 1990; Pezard et al., 1990; 1992). This fourth method is the most direct in that it yields a continuous record of the borehole and thus avoids the commonly poor recovery of cores in fractured intervals.

The FMS and BHTV also provide borehole diameter measurements that can be used to identify breakouts (Newmark et al., 1984; Newmark et al., 1985b; Zoback et al., 1985; Hickman et al., 1985; Plumb and Hickman, 1985); these breakouts, when stress induced, indicate the directions of the horizontal principal stress (Hottman et al., 1979, Bell and Gough, 1979) and hence constrain the present tectonic regime.

For all these reasons, the use of FMS and BHTV logging tool strings was planned during Leg 147 . However, only Hole $894 \mathrm{G}$ could be logged and only the FMS operated properly and provided usable data. This paper therefore presents an analysis of the FMS data in order to characterize both the borehole geometry and the fractures at Site 894. Because the low core recovery and poor FMS data quality did not 
allow us to match individual core pieces to FMS images, a global correlation between FMS fracture picks and core fracture measurements is proposed. The tectonic implications of these results are discussed in a companion paper (MacLeod, Célérier, et al., this volume).

\section{Formation MicroScanner}

The Formation MicroScanner is an extension of the dipmeter technology (Allaud and Ringot, 1969) introduced by Schlumberger in 1986 (Ekstrom et al., 1987). The FMS used by ODP since 1989 (Leg 126 ) is a slim version that can run through the drill pipe (Pezard et al., 1990; Shipboard Scientific Party, 1990a, 1990b); it is composed of the General Purpose Inclinometry Tool (GPIT) that contains a threecomponent magnetometer and accelerometer that give the orientation of the downhole sensors within the borehole, the orientation (azimuth and deviation) of the borehole itself and the magnetic field (inclination, declination, and intensity), and of the Microelectric Scanning Tool (MEST-B), which carries four orthogonal pads that are pressed against the borehole wall; each pad carries an array of 16 electrodes that is sufficiently dense to produce high-resolution resistivity images of the borehole wall. However, proper pad contact with the formation is ensured only in holes of a diameter smaller than $37 \mathrm{~cm}$.

\section{DRILLING HOLE 894G}

Hole $894 \mathrm{G}$ is located at $3023.4 \mathrm{~m}$ below sea level (mbsl) on the summit of the intrarift ridge (Fig. 1). Mainly gabbros were drilled (Fig. 2). Relevant operational information is summarized here but further details can be found in Shipboard Scientific Party (1993c).

A hard-rock guide base was set in order to stabilize the 3-km-long drill string. After alignment problems while reentering the hole and attempting to set a casing string, and subsequent evidence of movement of the hard-rock guide base, the hole was drilled with a $143 / 4$ in. $(37.5 \mathrm{~cm})$ bit to $40 \mathrm{~m}$ below sea floor ( $\mathrm{mbsf}$ ) and a $133 / 8$ in. (34.0 $\mathrm{cm}$ ) casing was set to $33 \mathrm{mbsf}$. Coring proceeded with a $97 / 8 \mathrm{in}$. $(25.1 \mathrm{~cm})$ bit to a total depth of $154.5 \mathrm{mbsf}$. Drilling conditions were difficult and it was necessary to wipe out, ream, and clean the hole after each core in order to reach the bottom again. High torque and bottom-hole assembly lateral wear suggested that ledges were interfering with the drill string, and drilling had to be abandoned after the pipe became stuck for 2.5 hours. The bad hole conditions are thought to have resulted from a large cavity at the top, which is likely to have impeded the proper evacuation of cuttings, and from a high fracture density in the gabbros, which might have deviated the hole and produced the ledges.

\section{LOGGING OPERATIONS AND LOG DATA}

During logging the deeper part of the hole could not be reached (Fig. 2). The High Temperature Lithodensity Tool (HLDT) recorded caliper data from 40 to 88 mbsf (Figs. 2,3) that showed that the hole, which had been drilled with a $25-\mathrm{cm}$ bit, had been enlarged in places to a width of up to $48 \mathrm{~cm}$ and was very rough; this meant that FMS data would be of poor quality, and thus the BHTV was run instead. After the failure of the BHTV tool and the loss of subsequent wells, it was decided to reoccupy Hole $894 \mathrm{G}$ and run the FMS after all, but to make multiple passes in partial compensation for the expected poor data quality. These five passes were run from 45 to 81 mbsf (Figs. 2, 3 ) without the heave compensator because the logged interval was too shallow. During the fifth pass the tool required a 34 kilonewtons pull to pass 51 mbsf (Fig. 4), after which the tool arms refused to close: the string was then lifted into the pipe and brought back with it; once on the rig floor it was found that one of the caliper arms was bent upward and wedged against the bit.
Table 1. Acronyms.

\begin{tabular}{|c|c|}
\hline Acronym & Full name and explanation \\
\hline & General \\
\hline mbsl & Depth in meters below sea level \\
\hline \multirow[t]{2}{*}{ mbsf } & $\begin{array}{l}\text { Depth in meters below seafloor } \\
\text { mbsf }=\text { mbrf }-3028 \mathrm{~m} \text { for HLDT run (Shipboard Scientific Party, } \\
\text { 1993c) }\end{array}$ \\
\hline & $\begin{array}{l}\text { mbsf }=\text { mbrf }-3025 \mathrm{~m} \text { for FMS runs (Shipboard Scientific Party, } \\
1993 \mathrm{c} \text { ) }\end{array}$ \\
\hline Shmin & Horizontal minimum principal stress direction \\
\hline Shmax & Horizontal maximum principal stress direction \\
\hline \multirow[t]{2}{*}{ POW } & Preferentially Oriented Washout (Dart and Zoback, 1989) \\
\hline & Tools \\
\hline BHTV & Borehole Televiewer \\
\hline HLDT & High Temperature Litho-Density Tool \\
\hline FMS & Formation MicroScanner string made of GPIT and MEST-B \\
\hline GPIT & $\begin{array}{l}\text { General Purpose Inclinometry Tool: magnetometer and } \\
\text { accelerometer }\end{array}$ \\
\hline \multirow[t]{2}{*}{ MEST-B } & $\begin{array}{l}\text { Microelectric Scanning Tool: Resistivity scanning electrode array: } \\
\text { B type is that used in ODP }\end{array}$ \\
\hline & Logs \\
\hline CALI & Hole diameter from HLDT caliper \\
\hline $\mathrm{Cl}$ & Hole diameter along Pad 1 from FMS caliper \\
\hline $\mathrm{C} 2$ & Hole diameter perpendicular to Pad 1 from FMS caliper \\
\hline PIAZ & Pad 1 azimuth with respect to magnetic North \\
\hline FX, FY, FZ, & 3 components of the magnetic field from GPIT magnetometer \\
\hline FNOR, FINC & Magnetic field intensity and inclination from GPIT magnetometer \\
\hline $\begin{array}{l}\text { AX, AY, AZ } \\
\text { ANOR }\end{array}$ & $\begin{array}{l}3 \text { components of the acceleration from GPIT accelerometer } \\
\text { Acceleration intensity from GPIT accelerometer }\end{array}$ \\
\hline $\begin{array}{l}\text { ANOR } \\
\text { HAZI, DEVI }\end{array}$ & $\begin{array}{l}\text { Acceleration intensity from GPIT accelerometer } \\
\text { Borehole azimuth and deviation }\end{array}$ \\
\hline RB & $\begin{array}{l}\text { Relative bearing of Pad 1; angle between the upper side of the hole } \\
\text { and Pad } 1 \text {, measured in a plane perpendicular to the borehole axis }\end{array}$ \\
\hline TENS & Cable tension \\
\hline $\mathrm{AzCmax}$ & Azimuth of the greatest of the two perpendicular measured diameters \\
\hline
\end{tabular}

The FMS caliper data confirm that the hole was greatly enlarged and are commonly "saturated," that is, the calipers have reached their maximum extension and do not record the actual hole diameter (Fig. 3 ). The $\mathrm{C} 2$ caliper readings of pass 5 are anomalous above the depth of $56 \mathrm{mbsf}$ which corresponds to the beginning of the overpull registered on Figure 4; this suggests that the tool was bent at that depth and became stuck in the hole $5 \mathrm{~m}$ above, where the overpull peaked. The inclinometry data from all five passes (Fig. 5) are consistent and indicate that the hole is deviated at about $4^{\circ}$ toward the southwest, which roughly agrees with the drift measurement (Shipboard Scientific Party, 1993c). The magnetic data are likewise very consistent (Fig. 6). The only exception to this general consistency occurs for pass 5 above 55 mbsf (Figs. 5, 6) for the reasons mentioned above. This consistency indicates that the tool remained reasonably well centered in the hole and was not swinging freely.

\section{HOLE GEOMETRY Methodology and Purpose}

Caliper measurements of two orthogonal borehole diameters ( $\mathrm{Cl}$ and $\mathrm{C} 2$ ) have been used to study borehole elongation since the technology to make these measurements became available first with the dipmeter (Cox, 1970; Babcock, 1978; Hottman et al., 1979; Schafer, 1980; Gough and Bell, 1981) and then with the FMS (Shamir et al., 1988; Shipboard Scientific Party, 1990b; Pezard et al., 1992). An older tool, the BoreHole TeleViewer (Zemanek et al., 1970a; Zemanek et al., 1970b), turned out to be more suited to these studies (Newmark et al., 1984; Newmark et al., 1985b; Zoback et al., 1985; Hickman et al., 1985; Morin et al., 1989) because it provides higher resolution measurement of the borehole shape and was used to confirm elongations inferred from caliper data (Plumb and Hickman, 1985).

The numerous possible causes of these frequently observed elongations are tentatively summarized in Table 2 (Beaudemont et al., 1988; Guenot, 1989; Dart and Zoback, 1989). However, most atten- 

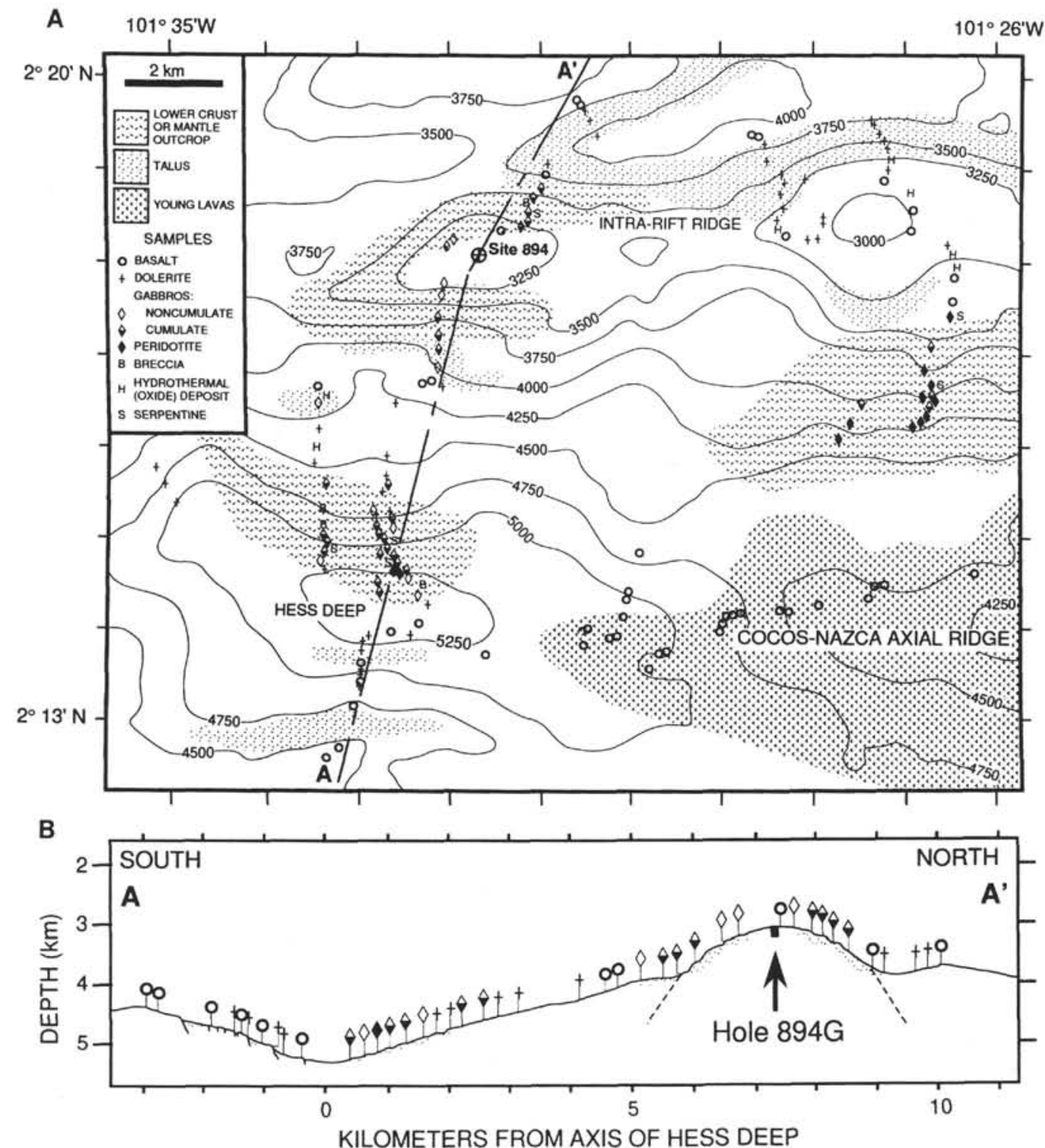

Figure 1. Location of ODP Site 894 and of samples collected during Nautile dives in Hess Deep (modified from Francheteau et al., 1990). A. Map. Bathymetric contours are labeled in meters. B. Cross section through Site 894 .

tion has recently focused on the relationship between the anisotropy of the horizontal state of stress and a particular type of borehole elongation termed breakouts. Breakouts are characterized by seven conditions: they were defined by Babcock (1978) as zones (1) of elongation, that is, where one diameter is significantly greater than the other (by at least $1 \mathrm{~cm}$ ), (2) that begin and end abruptly, (3) that persist for a significant depth interval (larger than the pad height), (4) that slow or stop the natural clockwise rotation of the tool, and (5) where the smallest measured caliper is equal to the drill-bit size; Plumb and Hickman (1985) added that breakouts (6) are of symmetrical elongation and (7) correspond to high electrical conductivity zones. Breakouts have been shown on three main grounds to be induced by remote anisotropic stress concentration around the borehole. First the theoretical calculation of the state of stress around a circular hole in an elastic impervious medium (Kirsch, 1898; Hubbert and Willis, 1957; Hottman et al., 1979; Bell and Gough, 1979), porous permeable medium (Haimson and Fairhurst, 1967), or poroelastic medium (Detournay and Cheng, 1988) shows that the stress difference is greatest along the direction of the minimum horizontal principal stress, Shmin, which is the preferred site of shear failure initiation. Second, the orientation of breakouts remains consistent between different formations within a well and between wells on a basin scale. Third, the Shmin direction deduced from breakouts coincides with that deduced from other stress indicators such as hydrofracturation directions or large-scale geological features (Bell and Gough, 1979; Gough and Bell, 1981, 1982; Fordjor et al., 1983; Zoback et al., 1985; Hickman et al., 1985; Plumb and Hickman, 1985; Morin et al., 1989, 1990). As a consequence, the term breakout now tends to indicate stress concentration-induced shear failure (Newmark et al., 1984; Zoback et al., 1985).

\section{Analysis}

\section{Preliminary Evaluation}

The azimuths of the longest of the two diameters measured at each pass are shown on Figure 7 and span almost all directions, which indicates that the hole is enlarged in many directions (i.e., is washed out). 


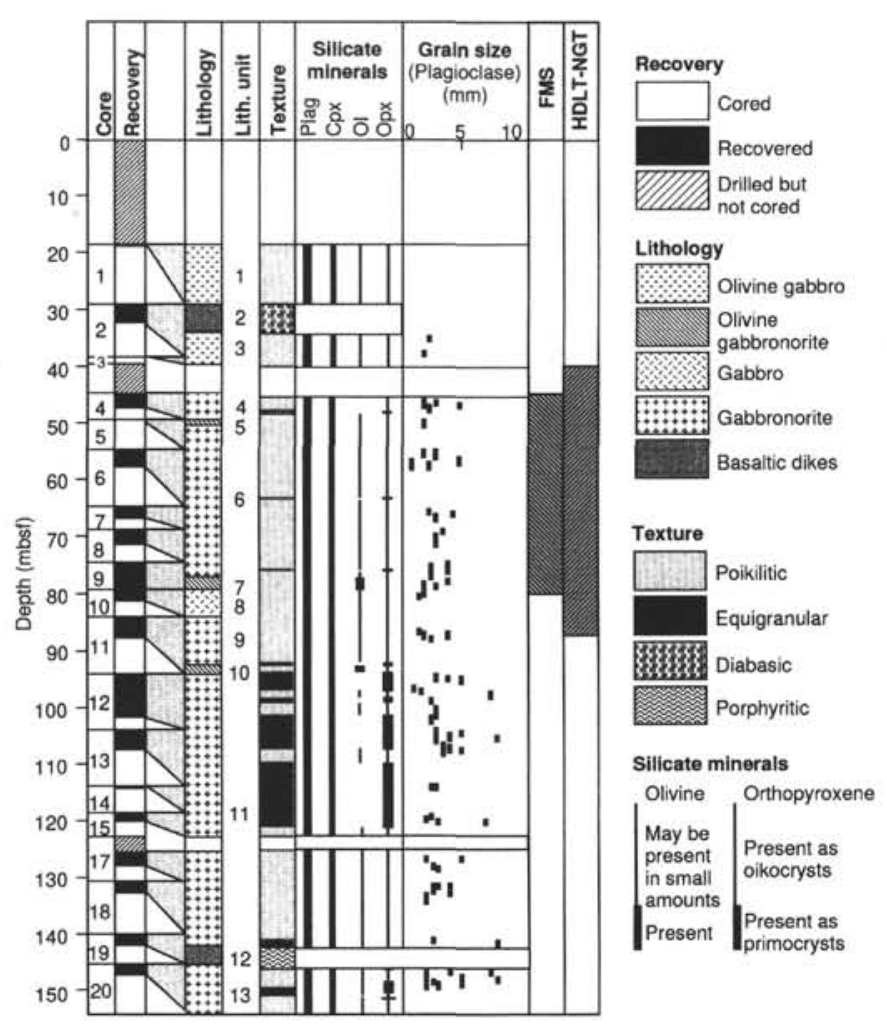

Figure 2. Stratigraphy of Hole 894G (from Shipboard Scientific Party, 1993c) and intervals logged with the FMS and NGT-HDLT (see Table 1 for acronyms).

However, these elongation azimuths are consistent in two short intervals: 51.2 to $52.5 \mathrm{mbsf}$ and 67.5 to $68.7 \mathrm{mbsf}$ (Fig. 7). Because these intervals correspond to a deviation of $4^{\circ}$ (Fig. 5) drill pipe wear may be involved (Table 2). Comparing the azimuth of these elongations with that of the borehole (modulo $180^{\circ}$ ) can be done directly (Figs. 5,7 ) or on the log of the relative bearing, RB, (modulo $90^{\circ}$ ) (Fig. 7); this shows that they differs by $30^{\circ}-40^{\circ}$ in the first interval but are almost identical in the second interval where RB remains close to either $0^{\circ}$ or $90^{\circ}$ (Fig. 7). This suggests that this second interval elongation may indeed be the result of drill pipe wear (Table 2).

To improve on this preliminary evaluation of the data requires adapting the processing criteria developed for good quality data to redundant lower quality data.

\section{Accounting for Washouts}

To account for the saturated caliper readings, the basic premises are that (1) if neither of the two calipers is saturated both the ellipticity and azimuth of the elongation direction can be obtained (Fig. 8A), (2) if only one of the two calipers is saturated the azimuth of the elongation direction is still indicated by the saturated caliper, even if the ellipticity cannot be constrained (Fig. 8B), and (3) if both calipers are saturated neither the elongation direction nor the ellipticity can be evaluated (Fig. 8C).

The width at which each caliper becomes saturated was determined both from Figure 3 and by choosing a cut-off that corresponds to a sudden increase in the width distribution (Fig. 9): $\mathrm{Cl}$ becomes saturated at $37.25 \mathrm{~cm}$ whereas $\mathrm{C} 2$ becomes saturated at $36.25 \mathrm{~cm}$. This implies that when both calipers are saturated, $\mathrm{C} 1$ records a maximum diameter that does not necessary indicate a larger hole diameter and that the data corresponding to that case in Figure 7 are misleading.

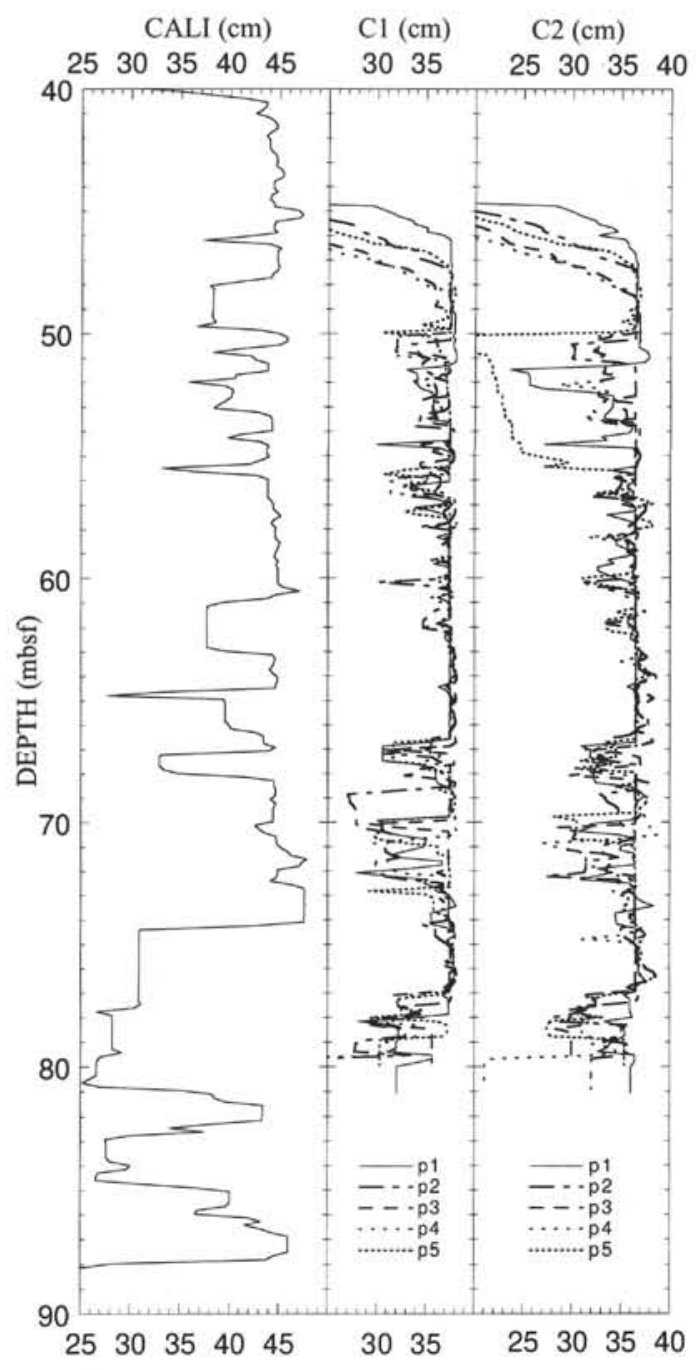

Figure 3. Borehole caliper measurements from the HDLT (CALI) and the FMS ( $\mathrm{C} 1$ and $\mathrm{C} 2)$. The FMS passes are labeled $\mathrm{p} 1$ through $\mathrm{p} 5$. Note that, for this particular tool, caliper $\mathrm{C} 1$ is fully open at $37.25 \mathrm{~cm}$, whereas caliper $\mathrm{C} 2$ is fully extended at $36.25 \mathrm{~cm}$. During the last pass, pass 5 , one of the tool arms (corresponding to $\mathrm{C} 2$ ) became bent at $\sim 56 \mathrm{mbsf}$, and the caliper data typically read less than the bit size.

A subsidiary question is whether the difference between these two values corresponds to a systematic measurement error that occurs even below saturation levels or to a different saturation threshold. This question arises because the precision of the caliper measurements is of the order of $0.6 \mathrm{~mm}$. To address it, we looked at the zones where neither of the two calipers was saturated and where two passes ran with perpendicular pad 1 azimuths, that is zones where the same diameters were measured by $\mathrm{C} 1$ during one pass and by $\mathrm{C} 2$ during the other; such measurements can differ by as much as $4 \mathrm{~cm}$ or can agree to within $2 \mathrm{~mm}$; this seems to indicate that the wall roughness is more important than measurement bias, if any.

To locate any possibly significant elongation, the azimuths of the greatest diameter were retained only if the following conditions were met:

1. One of the two measured diameters is not saturated (as in Fig. 8A, B). 


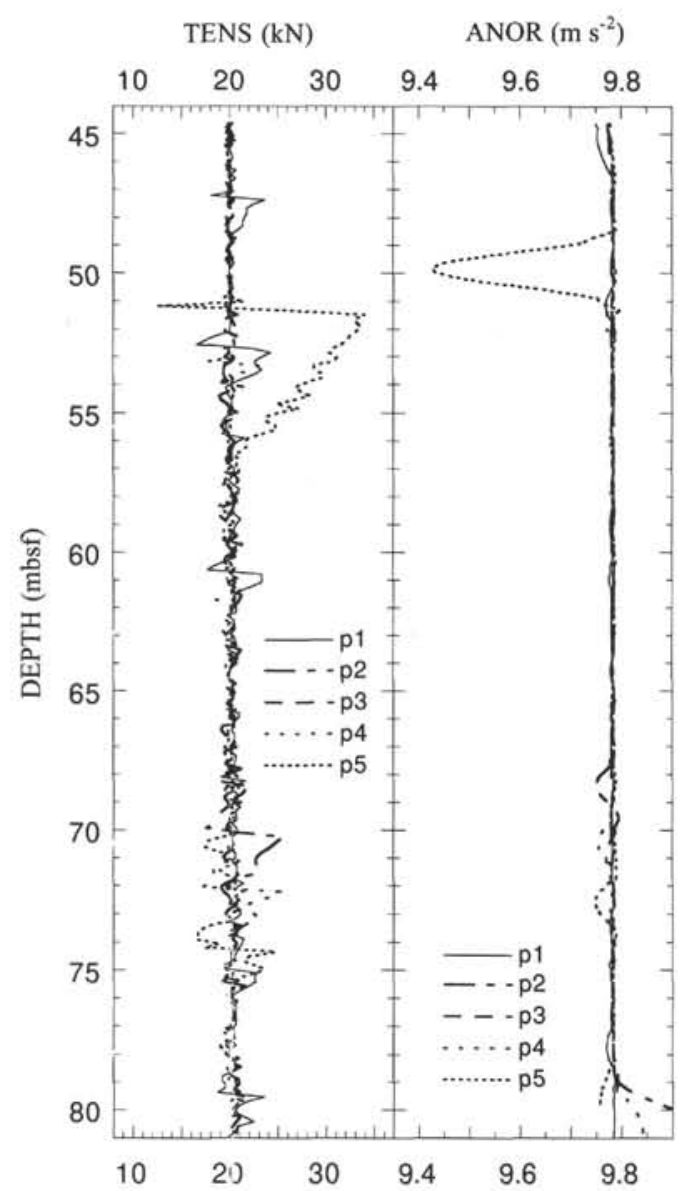

Figure 4. Cable tension (TENS) and tool acceleration (ANOR) during the five FMS passes.

2. The difference in caliper readings exceeds $2.54 \mathrm{~cm}$ ( 1 in.); this threshold is larger than that usually chosen in similar filtering (Shipboard Scientific Party, 1993b; MacLeod and Pratt, 1994) because of the general hole enlargement.

Plotting these filtered azimuth with respect to depth (Fig. 10) and selecting depth interval at least $60 \mathrm{~cm}$ long where these azimuths are stable defines nine areas of possibly significant elongation, labeled from A to I, that are reported in Tables 3 and 4.

\section{Single Pass Analysis}

For each of the nine areas, A to I, we went back to the caliper and azimuth log of each pass (Fig. 11) and determined the intervals where one of the following criteria is satisfied: (1) the pad 1 azimuth is stable (i.e., the tool stopped rotating) on an interval longer than $40 \mathrm{~cm}$, (2) the caliper difference is significant (more than $2.5 \mathrm{~cm}$ ) on an interval longer than $40 \mathrm{~cm}$, or (3) there is a detectable caliper difference that is either smaller than the $2.5 \mathrm{~cm}$ threshold or that occurs on intervals shorter than $40 \mathrm{~cm}$.

The intervals that satisfy (1) or (2) are reported in Table 3 under the $\mathrm{Az}$ and $\Delta \mathrm{C}$ heading respectively; those that satisfy (3) are reported as an "indication" under the $\Delta \mathrm{C}$ heading; if an interval satisfies both (1) and either (2) or (3) the azimuth of the largest diameter is reported in Table 4; if it satisfies both (1) and (2), it satisfies the classical single pass breakouts criteria, except that the minimum diameter is above bit size, and it is outlined in Tables 3 and 4 .

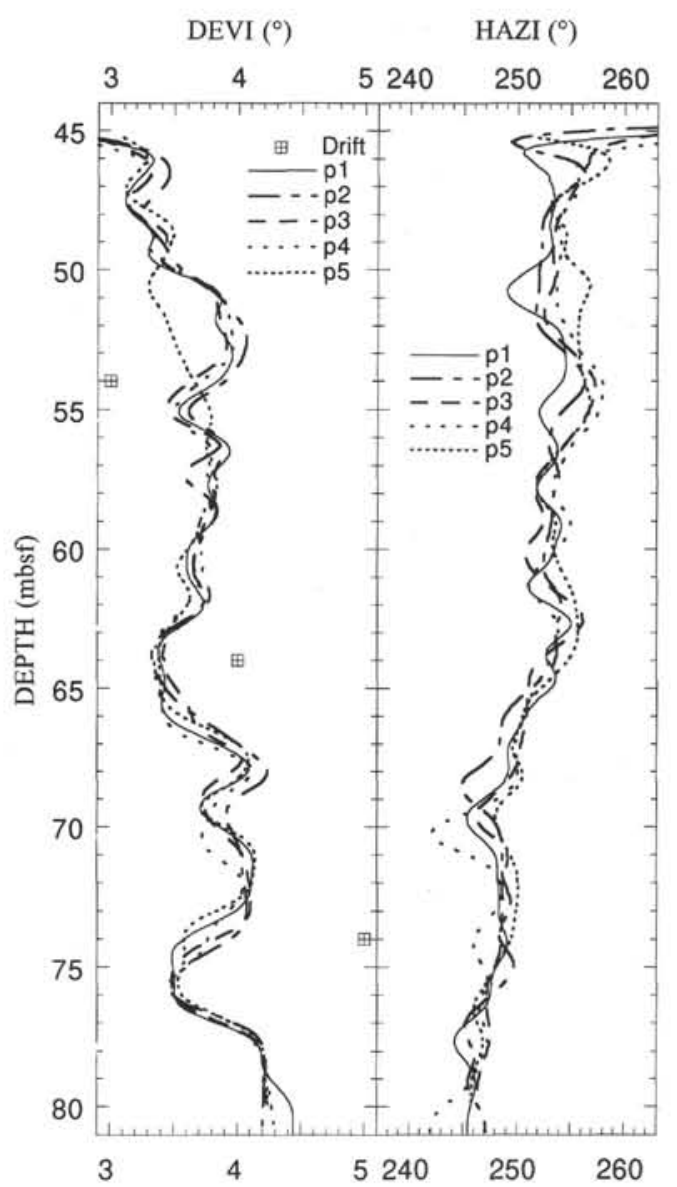

Figure 5. Hole deviation (DEVI) and azimuth (HAZI) as measured by the FMS tool during the five logging passes. The results of the drift survey (Shipboard Scientific Party, 1993c) are also reported on the deviation log. Azimuth is with respect to magnetic north.

Each of the nine previously defined intervals, except interval A, satisfies the classical single pass breakouts criteria for one and only one pass (Table 3 ).

Interval $\mathrm{A}$ is the clearest case for breakout as it satisfies its criteria for each pass except pass 5 where the caliper arm was bent. Passes 3 and 4 are almost identical within interval $\mathrm{A}$ and suggest an east-west elongation direction that is consistent with that of pass 1 but inconsistent with that of pass 2 (Fig. 11; Table 4).

\section{Exploiting Redundancy}

The multiplicity of passes allow to complete the above analysis by putting all the diameter measurements together in space. However this raises the problem of the position of the tool center: the same measured diameters could correspond to an enlargement either located on one side of the hole (Fig. 12A), distributed on both sides (Fig. 12B), or located on the other side (Fig. 12C). Because this ambiguity cannot be resolved with the available data, we will represent only one-half of the well and represent all the measured widths in excess of the bit size on that side (as in Fig. 12A); this representation transforms an originally elliptical shape (Fig. 12B) into a figure that conserves the length and orientation of the original diameters but is no longer an ellipse (Fig. 12A). This approach also implies that the criterion of symmetry of the elongation used for the detection of breakouts (Plumb and Hickman, 1985) cannot be verified. This rep- 


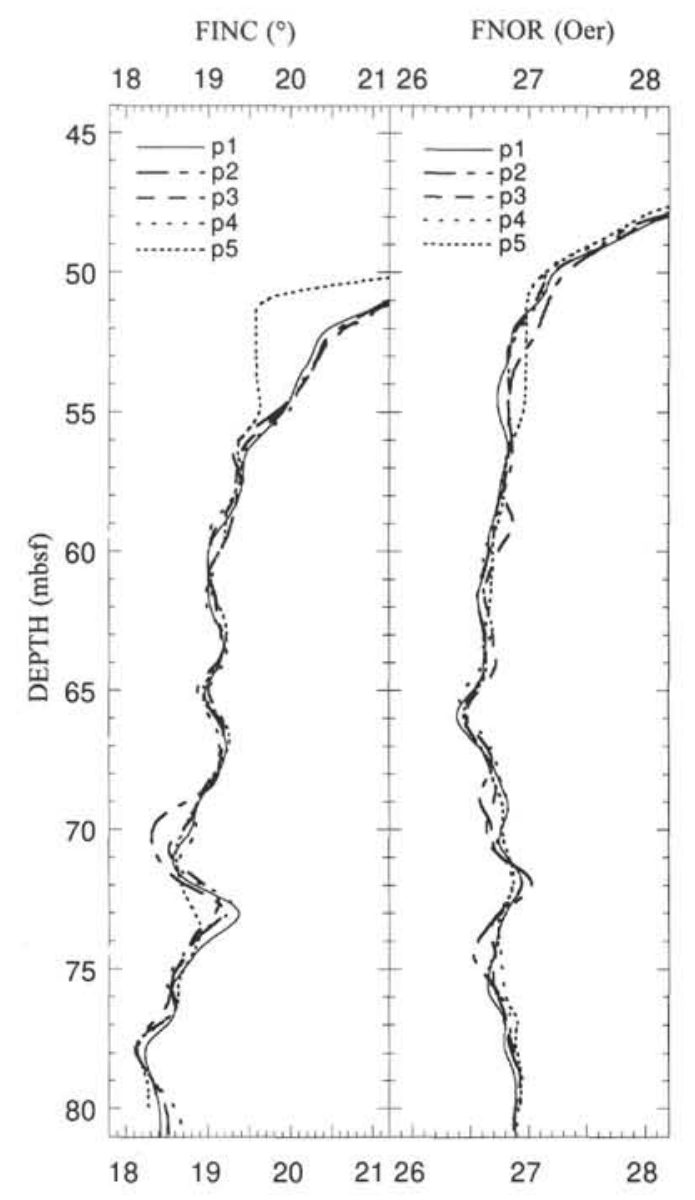

Figure 6. Magnetic inclination (FINC) and intensity (FNOR) as measured by the FMS tool during the five logging passes.

resentation can be done either in perspective or as or a view from the top of the half well. The perspective has the advantage of revealing the evolution with depth but the drawback of distorting length thus of making the shape discussion difficult. The top views reveal the borehole shape accurately, but only if this shape does not evolve abruptly within the represented interval; for this reason views from the top are preferred and shown for each of the nine intervals A to I (Fig. 13).

All of these intervals are clearly washouts but most are preferentially oriented washouts (POWs), as defined by Dart and Zoback (1989). The saturated pad directions help define the orientations of maximal enlargement whereas consistent smaller unsaturated values help define the orientations of minimal enlargement (Table 4). The east enlargement direction already noticed in the single pass analysis is present in intervals A, B, E, and F. Two pairs of orthogonal enlargement directions appear: an east-northeast and south-southeast pair in intervals $\mathrm{C}, \mathrm{F}, \mathrm{G}$, and $\mathrm{H}$ and a north-northeast and east-southeast pair in intervals A, G, and I; this second pair is restricted to the upper part of interval A and disappears in the subinterval A2 (Fig. 13).

If the borehole shape evolves abruptly with depth, the diameter measurements along the same azimuth become inconsistent (intervals $\mathrm{A}, \mathrm{D}, \mathrm{G}$, and $\mathrm{H}$ ). This inconsistency is the expression of the hole roughness that hinders the interpretation (Dart and Zoback, 1989).

\section{Discussion}

Combining the information of all the passes on the top views significantly alters the interpretation that would result from the analysis of a single pass in the case of washed out holes, even if large azimuthal data gaps persist in the combined data (intervals A, B, C, D, and F; Fig. 13; Table 4). An instance where the interpretation is modified can be seen in interval C: the analysis of pass 1 yields a reasonable N1 $10^{\circ}$ enlargement (Fig. 11; Table 4) but the combined data show two other orientations where the hole is also quite enlarged but that do not satisfy breakouts criteria on any single pass (Fig. 1; Table 4). An example where the combined data helps correct misleading clues obtained from a single pass is seen in interval D: it exhibits most of the breakout characteristics on pass 5 and yields consistent enlargement azimuth on passes 3,4 , and 5 (Table 4 ) but the top view shows a general washout with no indication of a preferential enlargement in one particular direction (Fig. 13).

The east-northeast direction of enlargement seen in intervals C, F, $\mathrm{G}$, and $\mathrm{H}$ is close to the borehole plunge direction and suggests a drill pipe wear due to borehole deviation (Table 2); this direction is always associated with an south-southeast direction of enlargement.

The east enlargement direction seen on intervals A, B, E, and F turns out to be along the strike of the fractures observed in Hole 894G and discussed below as well as along the strike of the major normal faults of Hess Deep (Fig. 1) and may thus be related to the rock anisotropy (Table 2).

Table 2. Causes of borehole elongation.

\begin{tabular}{|c|c|}
\hline Cause & References \\
\hline $\begin{array}{l}\text { 1. Failure controlled by formation anisotropy } \\
\text { Elongation is along fracture strike } \\
\text { Elongation is perpendicular to rock foliation } \\
\text { Elongation is influenced by natural fracture direction }\end{array}$ & $\begin{array}{l}\text { Babcock, } 1978 \\
\text { Guenot, 1989 } \\
\text { Brown, 1978; Schafer, } 1980\end{array}$ \\
\hline $\begin{array}{l}\text { 2. Failure controlled by remote anisotropic state of stress } \\
\text { 2a. Tensile failure along Shmax } \\
\text { Natural or induced hydrofracturing } \\
\text { Thermally induced fracturing } \\
\text { Reopening of vertical fracture striking about shmax }\end{array}$ & $\begin{array}{l}\text { Hubbert and Willis, 1957; Haimson and Fairhurst, 1967; Haimson, } 1978 \\
\text { Morin et al., 1990; Guenot, } 1987 \\
\text { Dart and Zoback, } 1989\end{array}$ \\
\hline 2b. Shear failure along Shmin & Hottman et al., 1979; Bell and Gough, 1979; Zoback et al., 1985 \\
\hline $\begin{array}{l}\text { 3. Failure controlled by instability } \\
\text { Symmetrical failure of an isotropic formation submitted to a remote isotropic load }\end{array}$ & Guenot. 1989 \\
\hline 4. Creep (in shales or halite) & Cheatham, 1984; Teufel, 1983; Bradley, 1979 \\
\hline $\begin{array}{l}\text { 5. Drilling induced formation wear } \\
\text { 5a. Drill pipe } \\
\text { Deviation is more than } 5^{\circ} \text { and } \\
\text { Elongation is oriented along the hole azimuth } \\
\text { Or elongation is oriented } 15^{\circ}-20^{\circ} \text { left of hole azimuth }\end{array}$ & $\begin{array}{l}\text { Babcock, 1978; Dart and Zoback, } 1989 \\
\text { Plumb and Cox, 1987; Plumb and Hickman, } 1985 \\
\text { Guenot, } 1989\end{array}$ \\
\hline $\begin{array}{l}\text { 5b. Drilling mud } \\
\text { Hydraulic erosion }\end{array}$ & Gaylord, 1983 \\
\hline
\end{tabular}




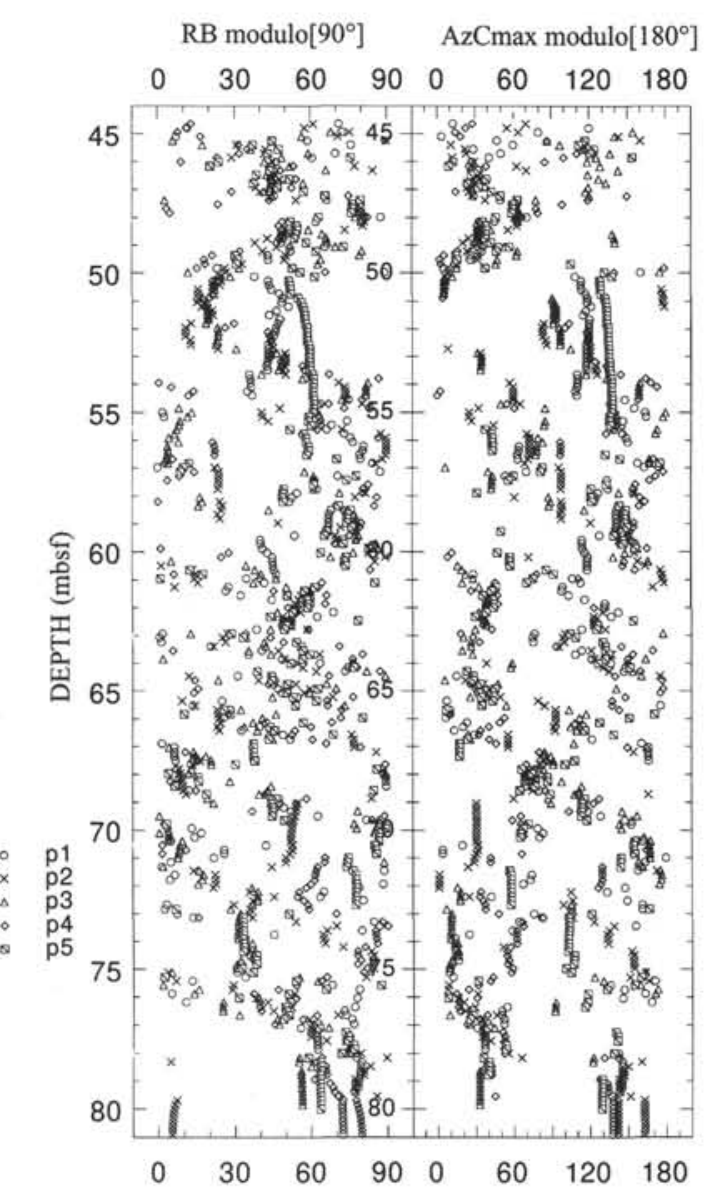

Figure 7. Pad 1 relative bearing (RB; Table 1) and azimuth ( $\mathrm{AzCmax}$ ) of the pad that corresponds to the larger measured diameter for each of the five passes, labeled from $\mathrm{p} 1$ to $\mathrm{p} 5$. Azimuth is with respect to magnetic north.

Notwithstanding the above-mentioned possible interpretations, the state of stress may also play a role in these preferred orientations of enlargement. A summary of focal mechanisms in the vicinity of the Triple Junction (MacLeod, Célérier, et al., this volume) suggests the direction of Shmin to be southeast to south-southeast along the Nazca-Galapagos plate boundary, northeast in the Cocos plate, southeast in the Pacific plate and generally south-southeast, but rather north-northeast close to Hess Deep, along the Cocos-Nazca rift. If the state of stress of the Hess Deep is consistent with that nearby along the Cocos-Nazca rift, the north-northeast enlargement direction may reflect some stress influence, whereas, if it is consistent with that of the Nazca-Galapagos plate boundary, the east-southeast to south-southeast enlargement directions could be stress related.

\section{FRACTURES}

\section{FMS Electrical Images}

The processed FMS resistivity images have a resolution on the order of a few millimeters and, if the conductivity contrast is large enough, can be used to detect features on the order of microns. The FMS images thus allow the direct mapping and the determination of the strike and dip of fractures as well as, when core recovery is sufficiently high, detailed correlation of cores and logging depth, and the orientation of cores (Ekstrom et al., 1987; Pezard and Luthi, 1988; Serra, 1989; Héliot et al., 1990; Pezard et al., 1990; 1992; MacLeod et al., 1992, 1994).

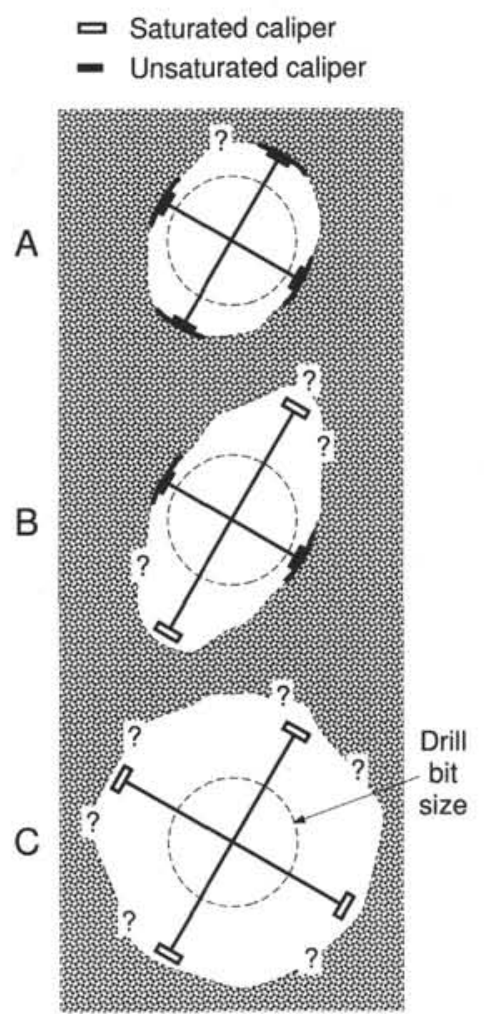

Figure 8. Effect of caliper saturation on elongation detection. A. Both pads are unsaturated: the direction and amplitude of the elongation are recorded. B. Only one pad is unsaturated: the direction and only a lower bound on the amplitude of the elongation are recorded. C. Both pads are saturated: only a lower bound on the amplitude of the enlargement is recorded but no information on its orientation is available.

\section{Quality}

The abundance of saturated caliper data in each logging pass shows that proper pad contact is not ensured on many depth intervals (Fig. 11) and suggests that the electrical images may be very poor within each of these intervals. This initial impression is confirmed by a superficial examination of the FMS images. However, the superposition of the caliper data of all of the passes (Fig. 3) shows that almost every depth interval was logged with an unsaturated caliper by at least one pass. This and the tool high sensitivity to conductive features encouraged us to carefully reprocess the data from the five passes to seek structural information on the good depth intervals of each pass.

\section{Processing}

The image data were reprocessed with the Z\&S "Recall" software on a Silicon Graphics workstation. This involved repairing buttons, that is replacing data collected by a defective sensor by values interpolated between the two nearest sensors, enhancing the images, and using very short-step dynamic normalization.

An attempt to merge two passes together was canceled because of two difficulties. First, the level of the formation gamma-ray was too low (Shipboard Scientific Party, 1993c) to help depth-correlate different passes; second, the lack of heave compensation and the intermittent sticking and pulling of the tool resulting from the borehole roughness yielded images that were stretched and compressed differently from pass to pass, even after the accelerometer correction was applied. 

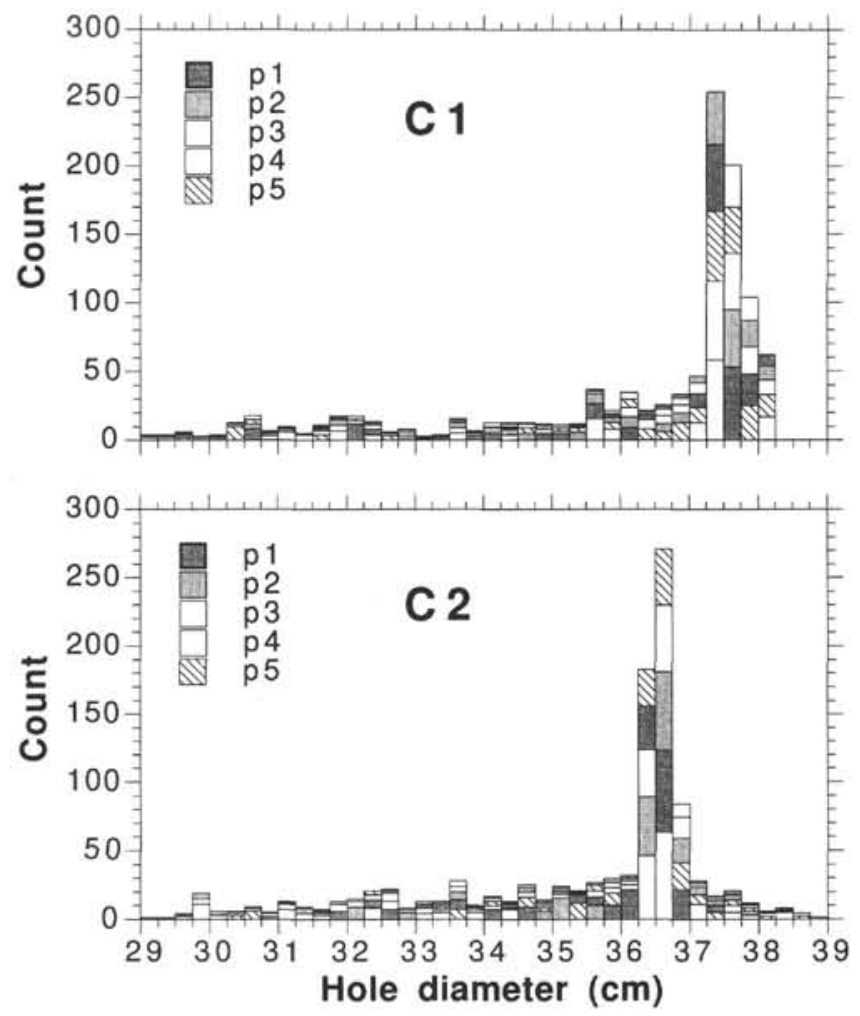

Figure 9. Histogram of the FMS caliper measurements from all five passes.

The only possible means of depth-correcting one set of images to another was by manually "eyeballing" individual low-resistivity features and making a decision as to whether or not they belong to the same plane. This method was very subjective and did not aid the identification of fracture planes. We thus decided to interpret each run separately.

\section{Interpretation}

After reprocessing, a large number of low-resistivity, irregular to planar features can be seen (Fig. 14); there is little doubt that these represent fractures, that are probably open and water-filled. Although more detail is seen in the areas of better pad contact (e.g., 50-55 mbsf; Fig. 14), planar fractures may be identified throughout the logged interval. In many instances the feature may be recognized on only two or three pads; this may be due either to the intersection and truncation of fractures or to poor pad contact with the high side of the borehole. In such cases there may be some ambiguity as to the orientation of the plane; hence, when picking fracture planes a quality rating from 1 to 3 was assigned to each feature (Table 5).

Fractures were picked systematically on each pass for the entire $35-\mathrm{m}$ logged interval and the picks from each of the five passes were summed together. Although there is some overlap and a number of planes have undoubtedly been picked more than once, the different passes tend to have recorded interpretable data in different intervals. Where overlap occurs it is most likely that the frequency of occurrence of the largest fractures is biased but that their orientation remains valid.

In Figure 15 the poles of fractures from all five passes together are subdivided by data quality. The three qualities show very similar trends overall, but, as might be expected, with a progressively greater dispersion of orientation in the lower quality picks. The preferred orientation of the poles, taken as the modal densities of the pole data,

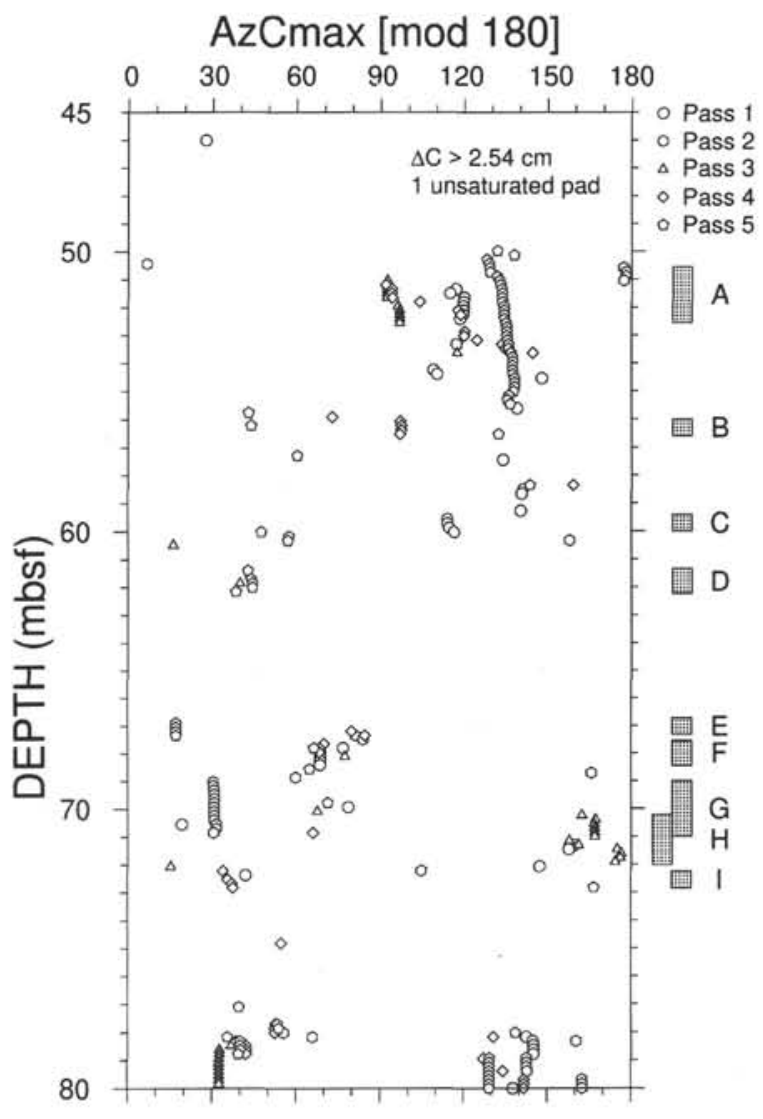

Figure 10. Azimuth (AzCmax; Table 1), modulo $180^{\circ}$, that corresponds to the larger diameter measured by any of the five passes when the two following conditions are met: (1) at least one of the two caliper measurements is not saturated and (2) the difference in caliper readings is more than $2.5 \mathrm{~cm}$ (1 in.). The intervals of interest are labeled A through $I$ and reported in Tables 3 and 4 . The data below $78 \mathrm{mbsf}$ are meaningless because the tool arms were not fully opened. Azimuth is with respect to magnetic north.

are given in Table 5. Combined, the borehole wall fracture data yield a preferred pole to plane of azimuth $354.4^{\circ}$ and plunge $39.7^{\circ}$, corresponding to a plane dipping at $50.3^{\circ}$ southward, with a strike of $084.4^{\circ}$ (Fig. 16B). Note the marked preferred east-west strike, parallel to the trend of the intrarift ridge at Site 894, the overall southward dip to the fractures, and the very few north-south-trending features.

\section{Core Structural Observations}

The cores from Hole $894 \mathrm{G}$ are cut by a dense network $(\sim 0.21$ veins per centimeter) of hydrothermal veins or lined fractures. These veins range from early, high-temperature amphibolite facies microveins to a predominant set of large, planar, tensile structures with greenschist (chlorite-prehnite) to zeolite (chlorite-smectite) facies mineralogy (Shipboard Scientific Party, 1993c).

During Leg 147 the orientations of 442 hydrothermal veins in Hole $894 \mathrm{G}$ cores were recorded relative to core-liner coordinates (defined in Shipboard Scientific Party, 1993a). Their average true dip, relative to the axis of the borehole, is $55.8^{\circ}\left( \pm 19.2^{\circ}\right)$. Of these veins, some 113 were measured from core pieces from which the stable, assumed primary, magnetic remanence had been isolated. Restoration of the orientations of these veins relative to the horizontal magnetization direction shows a marked preferred trend, with a north-west to 
Table 3. Intervals of elongation in Hole 894G (mbsf).

\begin{tabular}{|c|c|c|c|c|c|c|c|c|c|c|c|c|}
\hline \multirow{2}{*}{$\begin{array}{l}\text { Depth } \\
\text { interval }\end{array}$} & \multicolumn{2}{|c|}{ AzCmax consistent } & \multicolumn{2}{|c|}{ Pass I } & \multicolumn{2}{|c|}{ Pass 2} & \multicolumn{2}{|c|}{ Pass 3} & \multicolumn{2}{|c|}{ Pass 4} & \multicolumn{2}{|c|}{ Pass 5} \\
\hline & After filter & Raw & $\Delta \mathrm{C}$ & $\mathrm{Az}$ & $\Delta \mathrm{C}$ & $\mathrm{Az}$ & $\Delta \mathrm{C}$ & $\mathrm{Az}$ & $\Delta \mathrm{C}$ & $\mathrm{Az}$ & $\Delta \mathrm{C}$ & $\mathrm{Az}$ \\
\hline \multirow[t]{2}{*}{ A } & 50.5 & 51.2 & 51.2 & 50.1 & 50.3 & 49.8 & 50.9 & 50.2 & 51.1 & 50.0 & & 50.1 \\
\hline & 52.5 & 52.7 & 52.8 & 54.4 & 51.2 & 52.7 & 52.7 & 53.6 & $\mathbf{5 3 . 6}$ & 52.0 & Bent arm & 56.5 \\
\hline \multirow[t]{2}{*}{ B } & 56.0 & & & 56.0 & & 55.8 & & 55.8 & 55.8 & 56.0 & & 50.1 \\
\hline & 56.6 & NO & NO & 56.6 & Indication & 56.8 & Indication & 57.0 & 56.6 & 56.5 & $?$ & 56.5 \\
\hline \multirow[t]{2}{*}{$\mathrm{C}$} & 59.4 & & 59.4 & 59.4 & & 59.1 & & 59.6 & & 57.6 & & 58.4 \\
\hline & 60.0 & NO & 60.0 & 60.8 & NO & 59.8 & NO & 60.3 & NO & 59.9 & NO & 59.8 \\
\hline \multirow[t]{2}{*}{ D } & 61.3 & & & & & 61.4 & & 61.4 & & 61.0 & 61.6 & 61.3 \\
\hline & 62.2 & NO & NO & NO & Indication & 62.8 & Indication & 62.8 & NO & 63.2 & 62.2 & 62.3 \\
\hline \multirow[t]{2}{*}{ E } & 66.8 & & & 67.0 & & 66.7 & & 67.0 & 67.2 & & 66.8 & 66.8 \\
\hline & 67.4 & NO & NO & 68.5 & Indication & 67.1 & Indication & 68.0 & 68.1 & NO & 67.4 & 67.4 \\
\hline \multirow[t]{2}{*}{$\mathrm{F}$} & 67.6 & 67.6 & 67.7 & 67.0 & & 67.8 & & 67.0 & 67.2 & 67.8 & & \\
\hline & 68.5 & 68.7 & 68.5 & 68.5 & Indication & 68.7 & Indication & 68.0 & 68.1 & 68.4 & Indication & NO \\
\hline \multirow[t]{2}{*}{ G } & 69.0 & & & & 69.6 & 69.0 & 70.0 & 70.3 & & 69.6 & & 68.9 \\
\hline & 71.0 & NO & Indication & NO & 71.0 & 71.2 & 72.1 & 71.9 & NO & 70.7 & Indication & 69.6 \\
\hline \multirow[t]{2}{*}{$\mathrm{H}$} & 70.2 & & & & 69.6 & 69.0 & 70.0 & 70.3 & & 71.0 & & 69.9 \\
\hline & 72.0 & NO & Indication & NO & 71.0 & 71.2 & 72.1 & 71.9 & Indication & 73.0 & NO & 72.7 \\
\hline \multirow[t]{2}{*}{ I } & 72.2 & & & & & & & 71.9 & 72.5 & 71.0 & & \\
\hline & 72.8 & NO & $\mathrm{NO}$ & NO & Indication & NO & NO & 75.0 & 72.9 & 73.0 & Indication & NO \\
\hline
\end{tabular}

Notes: $\mathrm{AzCmax}=$ depth interval where the azimuth of the longest axis is consistent between passes. $\Delta \mathrm{C}=$ depth interval where $\Delta \mathrm{C}>2.5 \mathrm{~cm}$. "Indication" $=\mathrm{a}$ slight caliper difference (below the threshold) is present. Az = depth interval where the azimuth of Pad 1 is stable (i.e., the tool does not rotate). Bold depth intervals satisfy the classical breakout characteristics for a particular pass, except that minimum caliper is above bit size.

Table 4. Azimuths of elongation in Hole 894G.

\begin{tabular}{|c|c|c|c|c|c|c|c|c|c|c|}
\hline \multirow[b]{2}{*}{$\begin{array}{l}\text { Depth } \\
\text { interval }\end{array}$} & \multirow{2}{*}{$\begin{array}{l}\text { AzCmax } \\
\text { vs. depth } \\
\text { Fig. } 10\end{array}$} & \multicolumn{5}{|c|}{$\begin{array}{l}\text { AzCmax individual passes } \\
\text { Fig. } 11\end{array}$} & \multicolumn{4}{|c|}{$\begin{array}{c}\text { Top views } \\
\text { Fig. } 13\end{array}$} \\
\hline & & Pass 1 & Pass 2 & Pass 3 & Pass 4 & Pass 5 & $\begin{array}{c}\text { Maximal } \\
\text { enlargement }\end{array}$ & $\begin{array}{c}\text { Minimal } \\
\text { enlargement }\end{array}$ & $\begin{array}{l}\text { Large azimuthal } \\
\text { data gap }\end{array}$ & $\begin{array}{l}\text { Inconsistent } \\
\text { with depth }\end{array}$ \\
\hline A & $\begin{array}{r}95 \\
120 \\
180\end{array}$ & 115 & 180 & 95 & 95 & & $\begin{array}{c}25-30 \\
85-95 \\
110-120\end{array}$ & & Yes & Yes \\
\hline B & 95 & & 70 & 80 & 95 & & 95 & $5-10$ & Yes & \\
\hline C & 115 & 110 & & & & & $\begin{array}{c}50-65 \\
110-115 \\
135-155\end{array}$ & $25-35$ & Yes & \\
\hline D & 40 & & 40 & 40 & & 40 & None & None & Yes & Yes \\
\hline E & 20 & & 55 & 90 & & 20 & & $\begin{array}{c}60-75 \\
145-170\end{array}$ & & \\
\hline F & 70 & 70 & 75 & 90 & 70 & & $\begin{array}{c}70-80 \\
85-95 \\
160-175\end{array}$ & & Yes & \\
\hline G & $\begin{array}{r}30 \\
170\end{array}$ & & 30 & 170 & & 110 & $\begin{array}{c}20-35 \\
55-70 \\
110-120 \\
140-155\end{array}$ & $75-85$ & & Yes \\
\hline $\mathrm{H}$ & $\begin{array}{r}30 \\
160 \\
170\end{array}$ & & 30 & 170 & 40 & & $\begin{array}{c}55-65 \\
150-175\end{array}$ & $70-130$ & & Yes \\
\hline I & 35 & & & & 40 & & $\begin{array}{c}30-40 \\
100-110\end{array}$ & & & \\
\hline
\end{tabular}

Note: Azimuth is with respect to magnetic North. Bold azimuths satisfy the classical breakout characteristics for a particular pass, except that minimum caliper is above bit size.

west-northwest strike and south-southwest dip (Shipboard Scientific Party, 1993a, 1993c).

The stable magnetic data from Hole $894 \mathrm{G}$ have a mean inclination of $+39.1^{\circ}\left( \pm 17.6^{\circ}\right)$, which contrasts with the expected inclination of $4.6^{\circ}$ for this latitude (Shipboard Scientific Party, 1993c). Mean stable inclinations from Site 895 , at approximately $+36^{\circ}$, are similar (Shipboard Scientific Party, 1993d), and suggest that the whole of the intrarift ridge may have suffered a tectonic rotation with a horizontalaxis component of this magnitude. Note that the west-northwest strike direction (relative to the stable remanence direction) of fractures in the core is not parallel to any local structural trend within
Hess Deep, leading to a suspicion that the rotation may also have included a vertical-axis component in addition to the horizontal-axis one. Without an external reference, however, it is not possible to confirm this premise or to consider the core data in their regional geographical contexts.

\section{Core-FMS Correlations}

Additional core paleomagnetic determinations made after the end of Leg 147 raise the number of reoriented core veins within the logged interval $45-80 \mathrm{mbsf}$ to 128 . The orientation distribution of 
Pass 1

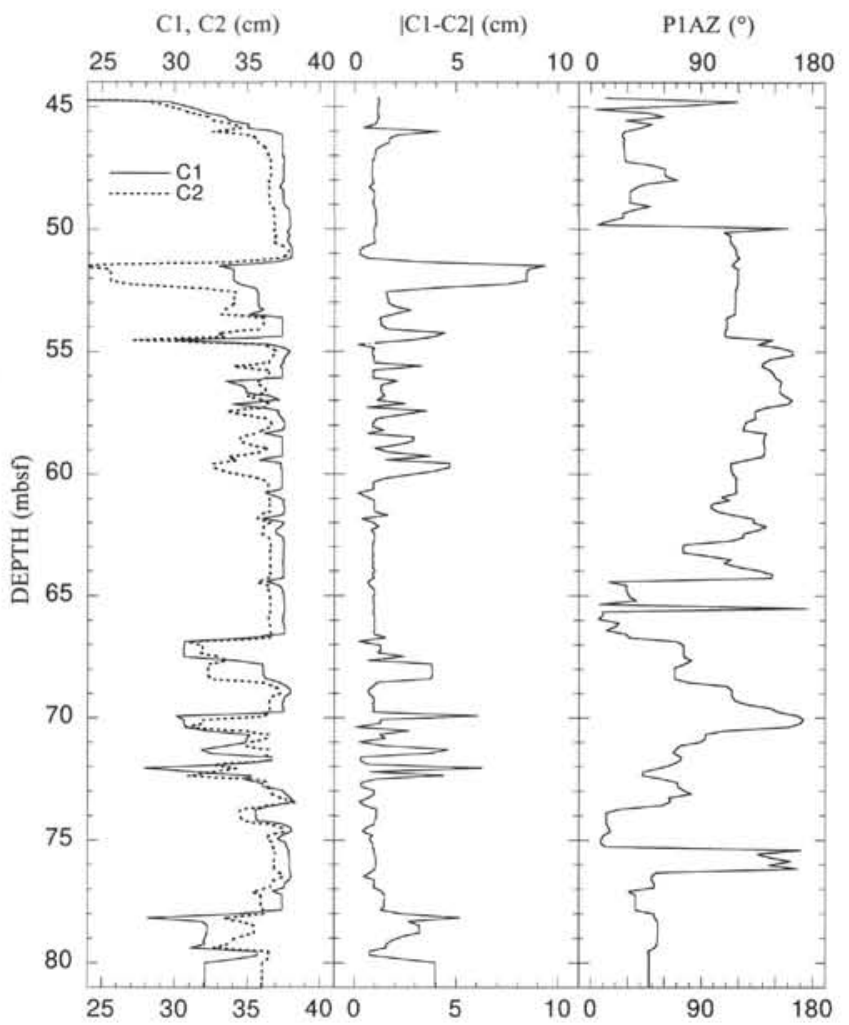

Pass 3

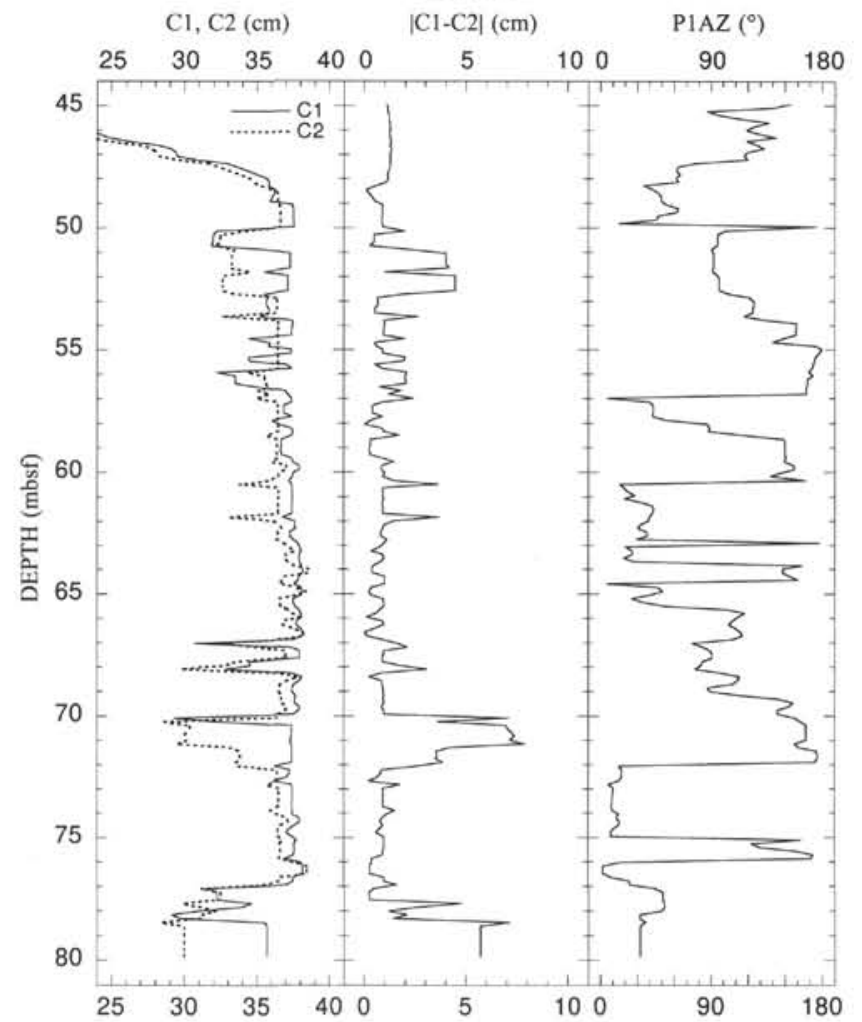

Pass 2

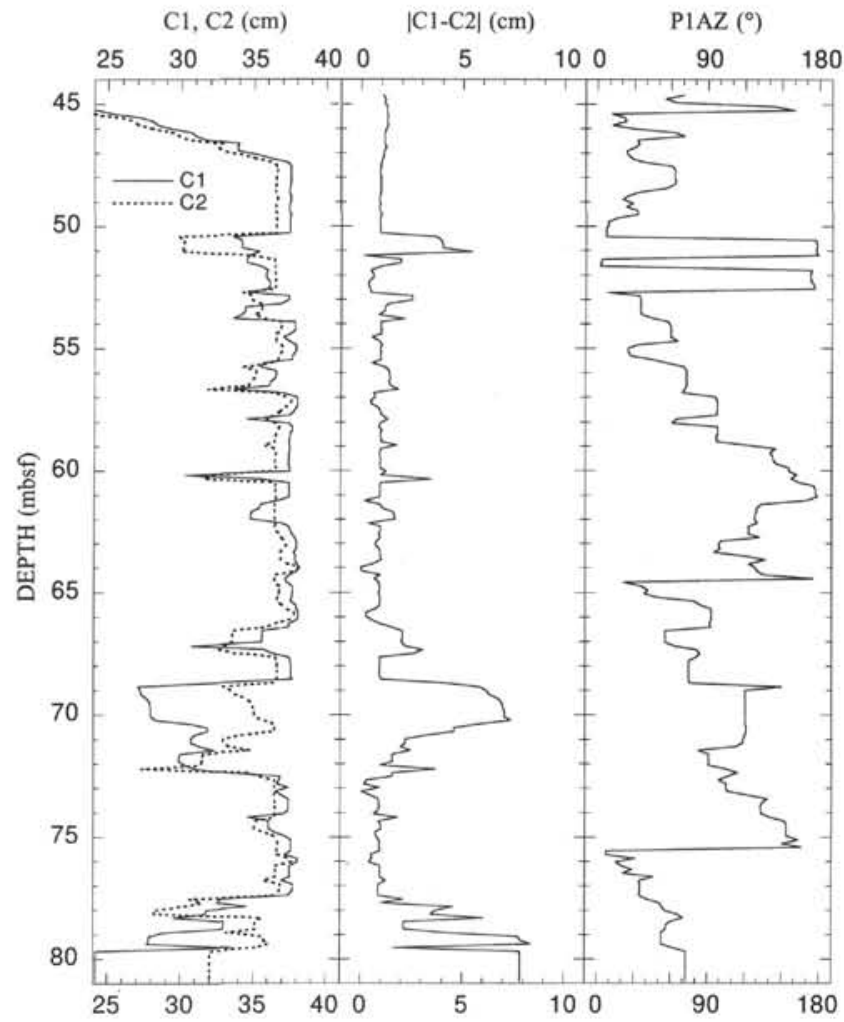

Pass 4

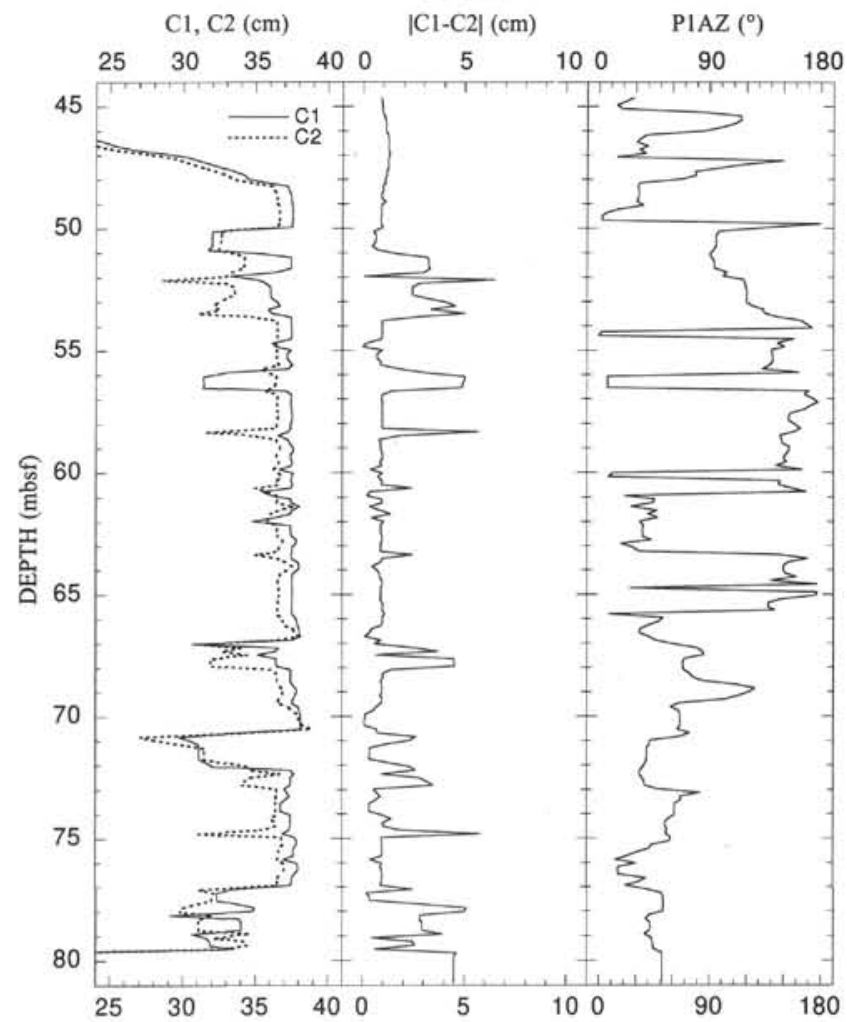

Figure 11. Caliper measurements $\mathrm{C} 1$ and $\mathrm{C} 2$ (Table 1), absolute value of the difference between $\mathrm{C} 1$ and $\mathrm{C} 2$, and pad 1 azimuth (P1AZ) for each of the five passes. Azimuth is with respect to magnetic north. 
Pass 5

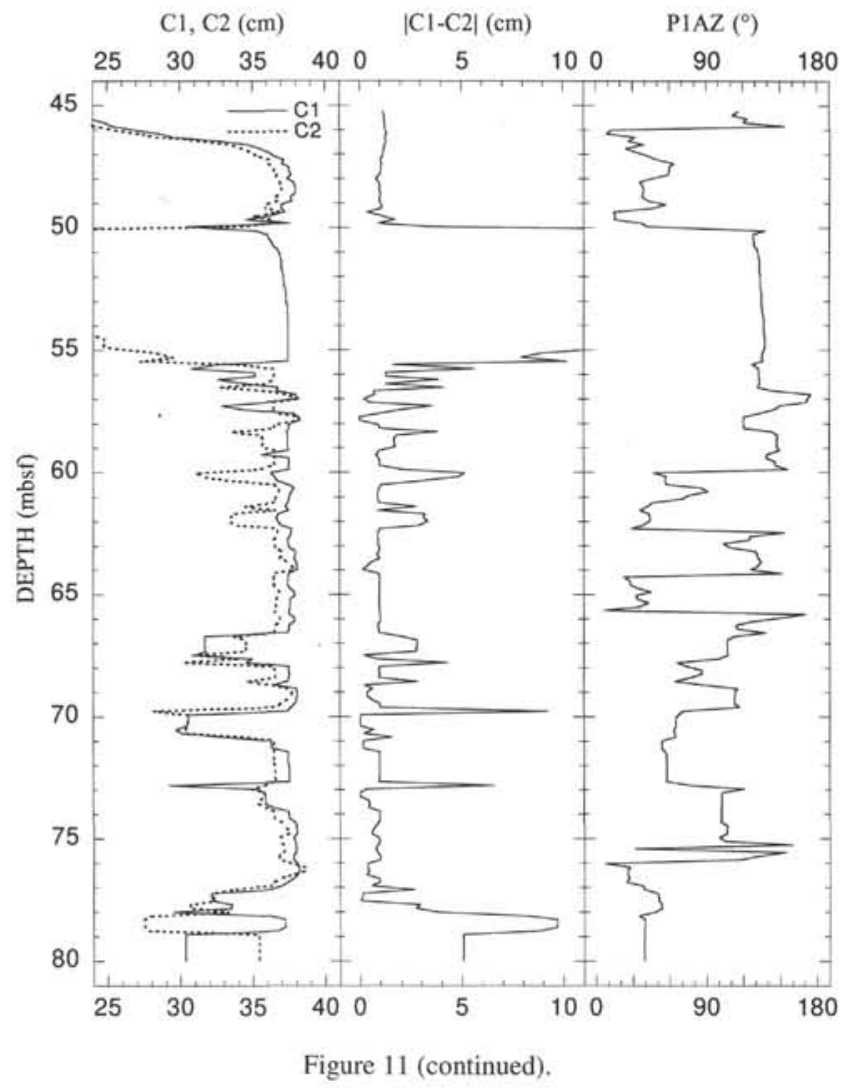

these veins (Fig. 16A) is representative of that derived from the cores of the whole borehole (Shipboard Scientific Party, 1993c; MacLeod, Célérier, et al., this volume). These veins are predominantly planar fractures and so are the low-resistivity features identified on the FMS images of the borehole wall. Most of the core veins are partially filled with chlorite clay minerals, but probably present enough residual fracture porosity to appear as low-resistivity features. Because of the poor quality of the FMS images and the low core recovery, it is not possible to match the features on a 1:1 basis; therefore, we instead compared the distribution of fracture data from the FMS with that from the core for the depth interval $45-80 \mathrm{mbsf}$ on a statistical basis (Fig. 16).

\section{Fracture Distribution}

The distributions of the fracture poles on both the cores and logs are very similar and show marked preferred orientations (stereonet plots on Fig. 16). Thus, there is little doubt that essentially the same features are compared.

The dip distributions are similar (Fig. 16), with a modal value of about $60^{\circ}$ and a slight underrepresentation of high angle dips in the FMS data. This can easily be explained by the fact that the FMS image consist of four vertical stripes that together cover only about $20 \%$ of the borehole wall surface (four pads of $5 \mathrm{~cm}$ width each in a borehole with a diameter of about $32 \mathrm{~cm}$ ); this means that this tool would detect only $20 \%$ of a population of vertical fractures that would have no preferred azimuth orientation.

The strike distributions of both data sets look similar with a modal value that represents up to $15 \%$ of the total (Fig. 16). However, this modal value is about $90^{\circ}$ relative to geographical north for the

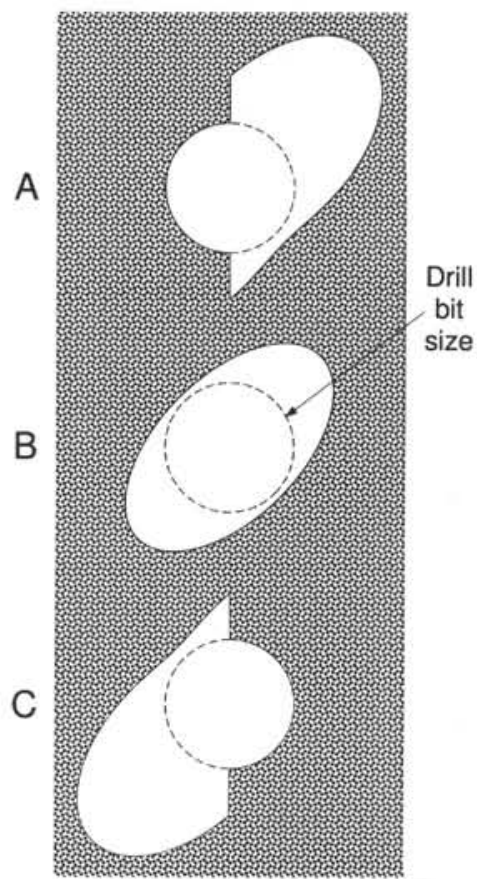

Figure 12. Effect of tool centering on elongation interpretation. The measured diameter along any known azimuth may correspond to an intermediate situation between two of the three following: $\mathbf{A}$. The enlargement is on the azimuth side of the hole. B. It is distributed evenly on both sides of the hole. C. It is on the opposite side of the hole. In all three of these typical situations, the diameters and azimuths are conserved, hence also the longest and shortest axis, but the bounding curve chosen as an ellipse in (B) is transformed into a nonelliptical curve in $(A)$ and $(C)$.

FMS data, whereas it is about $120^{\circ}$ relative to paleomagnetic north for the core data. Matching the two data sets implies that the stable magnetic remanence of the Hole $894 \mathrm{G}$ gabbros points toward $30^{\circ}-$ $40^{\circ}$ north.

\section{Discussion}

This $30^{\circ}-40^{\circ}$ north paleomagnetic declination is too large to be explicable in terms of secular variation in rocks that are thought to have cooled slowly close to the Equator at about $1 \mathrm{Ma}$ ago. It is better explained by a tectonic rotation. The core-log comparison implies a vertical-axis component of rotation of either $30^{\circ}-40^{\circ}$ counterclockwise (if the rocks are of normal polarity) or $140^{\circ}-150^{\circ}$ clockwise (if the rocks are of reversed polarity, i.e., magnetic north is close to geographical south). The former is obviously preferred in the absence of any other geological evidence for such a large rotation. Although the gabbros of Site 894 were previously thought to be of reversed polarity (Shipboard Scientific Party, 1993c), simply on the basis of their supposed $1 \mathrm{Ma}$ age, the results here suggest that they are more likely normally polarized.

The anomalous magnetic inclination data from the cores have already been interpreted in terms of horizontal-axis tectonic rotation (Shipboard Scientific Party, 1993c). They point down plunge, which implies tilting of the succession toward the north, assuming normal polarity. The interpretation of the vertical and horizontal components of rotation here identified, as well as whether they are part of a single rotation about an inclined axis, or whether they result from multiple rotation episodes is further discussed in the companion tectonic paper (MacLeod, Célérier, et al., this volume). 

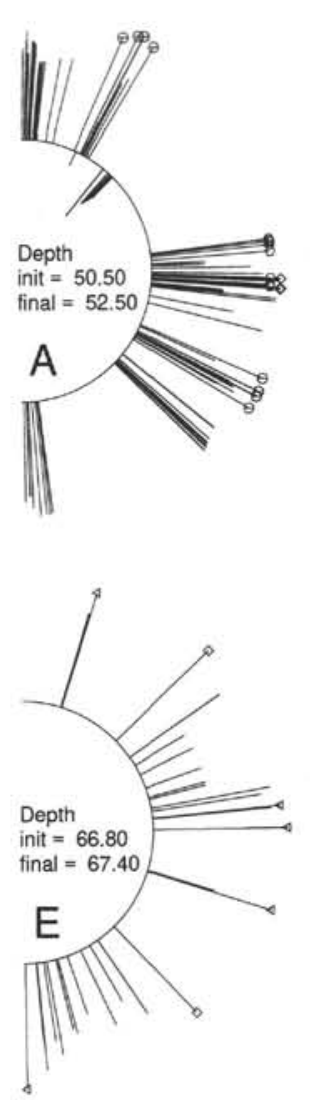
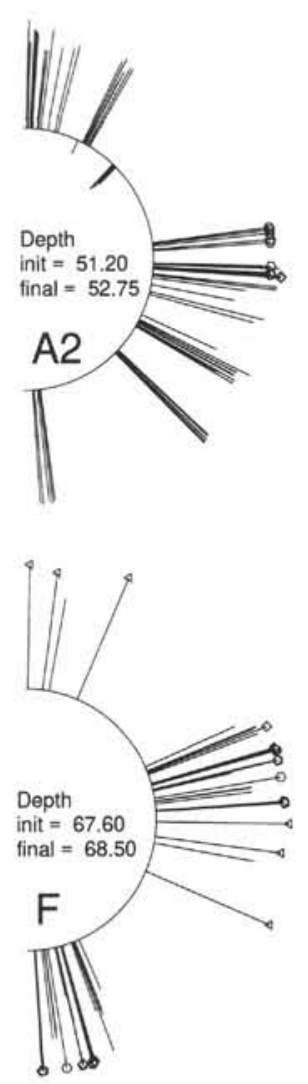
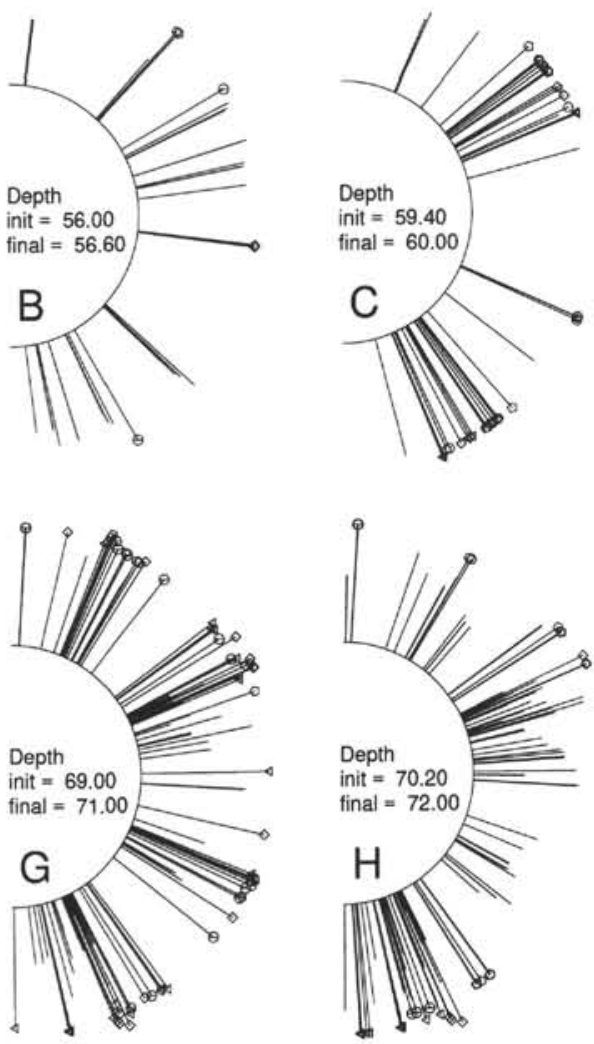

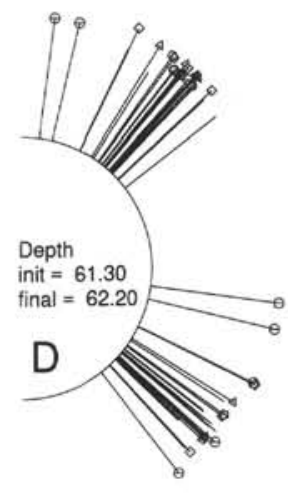

Saturated calipers

$\ominus$ Pass 1

- Pass 2

$\triangleleft$ Pass 3

- Pass 4

o Pass 5

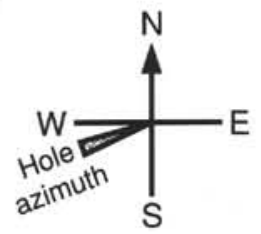

Figure 13. Representation of the hole shape looking directly down the hole, deduced from all five passes and represented as in Figure 12A for the nine intervals of Table 3 and the subinterval A2. The half circle represents half the hole at the bit size of $25.1 \mathrm{~cm}$, the azimuth of the spokes is that of the pad (modulo $180^{\circ}$ ), and the spoke length is equal to the measured diameter minus the bit size. Spokes with a symbol at the end correspond to a saturated measurement (i.e., a wide open caliper), and thus to an enlargement greater than measured; in that case the symbol is different for each pass. Azimuth is with respect to magnetic north. The measurements in interval $\mathrm{A}$ and $\mathrm{A} 2$ that are smaller than bit size correspond to those made by the bent arm.

\section{CONCLUSION}

Despite a very rough and washed-out borehole, the FMS data provide strong constraints on the fracture orientations and suggest a few directions of preferential enlargement. These results are obtained because five redundant logging passes were recorded to compensate for the expected low data quality and because the now classical analysis of FMS data has been adapted to this situation of multiple passes and a washed-out borehole. In particular, merging the information gathered on the separate passes may strongly alter interpretations based on a single pass of low quality data.

An east enlargement direction is thought to be related to the eastwest strike of the dense network of fractures observed both in the cores and on the FMS resistivity images, and an east-northeast enlargement direction may be the result of drill pipe wear along the borehole plunge direction. Additional east-southeast to south-southeast and north-northeast enlargements may reflect the influence of either the Nazca-Galapagos or the Cocos-Nazca plate boundary state of stress, respectively. However, the interpretation of these poorly defined directions remains uncertain.

The FMS resistivity images show mainly east-west striking and southward dipping fractures and very few north-south-trending features. This suggests a strong Cocos-Nazca control on brittle deformation in the Hess Deep. The distribution of fracture orientations identified on the FMS images is very similar to that obtained from core veins reoriented relative to paleomagnetic north. Matching the two sets together requires that the remanent magnetization direction points north-northwest. The preferred interpretation of this result is a vertical-axis tectonic rotation of $30^{\circ}$ to $40^{\circ}$ counterclockwise.

This study shows that the FMS data are robust and can be useful in poor quality holes. It implies that more complete borehole coverage available with the BHTV could substantially constrain the borehole shape and eventually help in understanding not only the local state of stress but also the causes of drilling difficulties encountered by ODP in hard rocks.

\section{ACKNOWLEDGMENTS}

Data acquisition was supervised by the Lamont Borehole Group with $\mathrm{BC}$ as Lamont logger and CJM as JOIDES logger. Most borehole shape analysis was carried out by $\mathrm{BC}$ with the help of CJM. FMS processing was carried out in the Borehole Research group at the University of Leicester by CJM with the help of BC and PHK using the "Recall" software of Z\&S Consultants Ltd. The Z\&S help desk, Jez Lofts, Gail Williamson, and Lee Ewert are all thanked for their assistance. CJM gratefully acknowledges funding in the form of a NERC ODP Special Topic Research Fellowship, and thanks Lin Kay for his support and encouragement. BC acknowledges CNRS and INSU Geosciences Marine support and thanks the Lamont Borehole Research Group for its particularly efficient handling of the data requests. Comments from Coleen Barton and an anonymous reviewer improved this paper; editing comments by Elsa Kapitan-White improved its presentation. 


\section{REFERENCES}

Allaud, L.A., and Ringot, J., 1969. The high resolution dipmeter tool. Log Analyst, 10:3-11.

Babcock, E.A., 1978. Measurement of subsurface fractures from dipmeter logs. AAPG Bull., 62:1111-1126.

Beaudemont, D., Ruhland, M., Gauer, P., and Janot, P., 1988. L'ovalisation des trous de forages-synthèse bibliographique. Rev. Inst. Fr. Pet., 43:389-403.

Bell, J.S., and Gough, D.I., 1979. Northeast-southwest compressive stress in Alberta: evidence from oil wells. Earth Planet. Sci. Lett., 45:475-482.

Bradley, W.B., 1979. Failure of inclined boreholes. J. Energy Resour. Technol., 101:232-239.

Brown, R.O., 1978. Application of fracture identification logs in the Cretaceous of north Louisiana and Mississippi. Trans. Gulf Coast Assoc. Geol. Soc., 28:75-91.

Cannat, M., and Pariso, J., 1991. Partial reorientation of the deformational structures at Site 735 using paleodeclination measurements. In Von Herzen, R.P., Robinson, P.T., et al., Proc. ODP, Sci. Results, 118: College Station, TX (Ocean Drilling Program), 409-414.

Cheatham, J.B., 1984. Wellbore stability. J. Pet. Tech., 36:889-896.

Cox, J.W., 1970. The high resolution dipmeter reveals dip-related borehole and formation characteristics. Trans. SPWLA Annu. Logging Symp., $11: 1-25$.

Dart, R.L., and Zoback, M.L., 1989. Wellbore breakouts stress analysis within the Central and Eastern continental United States. Log Analyst, 30:5497-5512.

Detournay, E., and Cheng, H.D., 1988. Poroelastic response of a borehole in a non-hydrostatic stress field. Int. J. Rock Mech. Min. Sci. Geomech. Abstr., 25:171-182.

Ekstrom, M.P., Dahan, C., Chen, M.-Y., Lloyd, P., and Rossi, D.J., 1987. Formation imaging with microelectrical scanning arrays, Log Analyst, 28:294-306.

Fordjor, C.K., Bell, J.S., and Gough, D.I., 1983. Breakouts in Alberta and stress in the North American plate. Can. J. Earth Sci., 20:1445-1455.

Francheteau, J., Armijo, R., Cheminée, J.L., Hekinian, R., Lonsdale, P.F., and Blum, N., 1990. 1 Ma East Pacific Rise oceanic crust and uppermost mantle exposed by rifting in Hess Deep (equatorial Pacific Ocean). Earth Planet. Sci. Lett., 101:281-295.

Gaylord, E.W., 1983. A laboratory study of the effects of hydraulics on hole erosion [paper presented at SPE 58th Annu. Tech. Conf., San Francisco, 1983].

Gough, D.I., and Bell, J.S., 1981. Stress orientations from oil well fractures in Alberta and Texas. Can. J. Earth Sci., 18:638-645.

Gough, D.I., and Bell, J.S., 1982. Stress orientations from borehole wall fractures with examples from Colorado, East Texas, and northern Canada. Can. J. Earth Sci., 19:1358-1370.

Guenot, A., 1987. Contraintes et ruptures autour des forages pétroliers. Proc. Int. Congr. Rock Mech., 6:109-118.

Guenot, A., 1989. Borehole breakouts and stress fields. Int. J. Rock Mech. Min. Sci. Geomech. Abstr., 26:181-195.

Haimson, B., and Fairhurst, C., 1967. Initiation and extension of hydraulic fractures in rocks. SPEJ, Soc. Pet. Eng. J., 7:310-318.

Haimson, B.C., 1978. The hydrofracturing stress measuring method and recent field results. Int. J. Rock Mech. Min. Sci. Geomech. Abstr., 15:167-178.

Héliot, D., Etchecopar, A., and Cheung, P., 1990. New developments in fracture characterisation from logs. In Maury, V., and Fourmaintraux, D. (Eds.), Rock at Great Depth: Rock Mechanics and Rock Physics at Great Depth: Rotterdam (Balkema), 3:1471-1478.

Hickman, S.H., Healy, J.H., and Zoback, M.D., 1985. In situ stress, natural fracture distribution, and borehole elongation in the Auburn Geothermal Well, Auburn, New York. J. Geophys. Res., 90:5497-5512.

Hottman, C.E., Smith, J.H., and Purcell, W.R., 1979. Relationship among Earth stresses, pore pressure, and drilling problems offshore Gulf of Alaska. J. Pet. Tech., 31:1477-1484.

Hubbert, M.K., and Willis, D.G., 1957. Mechanics of hydraulic fracturing. $J$. Pet. Tech., 9:153-168.

Kessels, W., and Kück, J., 1992. Computer-aided matching of plane core structures with borehole measurements for core orientation. Sci. Drill., 3:225-238.

Kirsch, G., 1898. Die Theorie der Elastizität und die Bedürfnisse der Festigkeitslehre. VDI-Z., 42:797-807.
Lonsdale, P., 1988. Structural pattern of the Galapagos microplate and evolution of the Galapagos triple junction. J. Geophys. Res., 93:13551-13574.

MacLeod, C.J., Parson, L.M., and Sager, W.W., 1994. Reorientation of cores using the Formation MicroScanner and Borehole Televiewer: application to structural and paleomagnetic studies with the Ocean Drilling Program. In Hawkins, J., Parson, L., Allan, J., et al., Proc. ODP, Sci. Results, 135 College Station, TX (Ocean Drilling Program), 301-311.

MacLeod, C.J., Parson, L.M., Sager, W.W., and the ODP Leg 135 Scientific Party, 1992. Identification of tectonic rotations in boreholes by the integration of core information with Formation MicroScanner and Borehole Televiewer images. In Hurst, A., Griffiths, C.M., and Worthington, P.F (Eds.), Geological Applications of Wireline Logs II. Geol. Soc. Spec. Publ. London, 65:235-246.

MacLeod, C.J., and Pratt, C.E., 1994. In situ stresses in the Lau Basin and Tonga forearc (southwest Pacific). In Hawkins, J., Parson, L., Allan, J., et al., Proc. ODP, Sci. Results, 135: College Station, TX (Ocean Drilling Program), 287-299.

Mével, C., Gillis, K.M., and Shipboard Scientific Party, 1993. Introduction and principal results. In Gillis, K., Mével, C., Allan, J., et al., Proc. ODP, Init. Repts., 147: College Station, TX (Ocean Drilling Program), 5-14.

Morin, R.H., Anderson, R.N., and Barton, C.A., 1989. Analysis and interpretation of the borehole televiewer log: information on the state of stress and the lithostratigraphy at Hole 504B. In Becker, K., Sakai, H., et al., Proc. ODP, Sci. Results, 111: College Station, TX (Ocean Drilling Program), 109-118.

Morin, R.H., Newmark, R.L., Barton, C.A., and Anderson, R.N., 1990. State of lithospheric stress and borehole stability at Deep Sea Drilling Project Site 504B, eastern Equatorial Pacific. J. Geophys. Res., 95:9293-9303.

Newmark, R.L., Anderson, R.N., Moos, D., and Zoback, M.D., 1985a. Sonic and ultrasonic logging of Hole 504B and its implications for the structure, porosity, and stress regime of the upper $1 \mathrm{~km}$ of the oceanic crust. In Anderson, R.N., Honnorez, J., Becker, K., et al., Init. Repts, DSDP, 83: Washington (U.S. Govt. Printing Office), 479-510.

Newmark, R.L., Zoback, M.D., and Anderson, R.N., 1984. Orientation of in situ stresses in the oceanic crust. Nature, 311:424-428.

, 1985b. Orientation of in situ stresses near the Costa Rica Rift and Peru-Chile Trench, Deep Sea Drilling Project Hole 504B. In Anderson. R.N., Honnorez, J., Becker, K., et al., Init. Repts. DSDP, 83: Washington (U.S. Govt. Printing Office), 511-514.

ODP Leg 147 Shipboard Scientific Party, 1993. Pacific lower crustal and shallow mantle sections recovered. Eos, 74:297, 307.

Pezard, P., Lovell, M., and ODP Leg 126 Shipboard Scientific Party, 1990. Downhole images: electrical scanning reveals the nature of subsurface oceanic crust. Eos, 71:709, 718.

Pezard, P.A., Lovell, M.A., and Hiscott, R.N., 1992. Downhole electrical images in volcaniclastic sequences of the Izu-Bonin forearc basin, western Pacific. In Taylor, B., Fujioka, K., et al., Proc. ODP, Sci. Results, 126: College Station, TX (Ocean Drilling Program), 603-624.

Pezard, P.A., and Luthi, S.M., 1988. Borehole electrical images in the basement of the Cajon Pass scientific drillhole, California: fracture identification and tectonic implications. Geophys. Res. Lett., 15:1017-1020.

Plumb, R.A., and Cox, J.W., 1987. Stress directions in Eastern North America determined to $4.5 \mathrm{~km}$ from borehole elongation measurements. $J$. Geophys. Res., 92:4805-4816.

Plumb, R.A., and Hickman, S.H., 1985. Stress-induced borehole elongation: a comparison between the four-arm dipmeter and the borehole televiewer in the Auburn geothermal well. J. Geophys. Res., 90:5513-5521.

Schafer, J.N., 1980. A practical method of well evaluation and acreage development for the naturally fractured Austin Chalk formation. Log Analyst, 21:10-23.

Searle, R., 1989. Location and segmentation of the Cocos-Nazca spreading centre west of $95^{\circ}$ W. Mar. Geophys. Res., 11:15-26.

Searle, R.C., and Francheteau, J., 1986. Morphology and tectonics of the Galapagos triple junction. Mar. Geophys. Res., 8:95-129.

Serra, O., 1989. Formation MicroScanner Image Interpretation: Houston (Schlumberger Educ. Services), SMP-7028.

Shamir, G., Zoback, M.D., and Barton, C.A., 1988. In situ stress orientation near the San Andreas fault: preliminary results to $2.1 \mathrm{~km}$ depth from the Cajon Pass scientific drillhole. Geophys. Res. Lett., 15:989-992.

Shipboard Scientific Party, 1985. Hole 504B, Leg 83. In Anderson, R.N., Honnorez, J., Becker, K., et al., Init. Repts. DSDP, 83: Washington (U.S. Govt. Printing Office), 13-118. 
, 1990a. Explanatory notes. In Taylor, B., Fujioka, K., et al., Proc. ODP, Init. Repts., 126: College Station, TX (Ocean Drilling Program), $13-42$.

-, 1990b. Site 792. In Taylor, B., Fujioka, K., et al., Proc. ODP, Init. Repts., 126: College Station, TX (Ocean Drilling Program), 221-314.

, 1992a. Explanatory notes, In Dick, H.J.B., Erzinger, J., Stokking, L.B., et al., Proc. ODP, Init. Repts., 140: College Station, TX (Ocean Drilling Program), 5-33.

, 1992b. Site 504. In Dick, H.J.B., Erzinger, J., Stokking, L.B., et al., Proc. ODP, Init. Repts., 140: College Station, TX (Ocean Drilling Program), 37-200.

, 1993a. Explanatory notes. In Gillis, K., Mével, C., Allan, J., et al., Proc. ODP, Init. Repts., 147: College Station, TX (Ocean Drilling Program), $15-42$.

, 1993b. Site 504. In Alt, J.C., Kinoshita, H., Stokking, L.B., et al., Proc. ODP, Init. Repts., 148: College Station, TX (Ocean Drilling Program), 27-121.

, 1993c. Site 894. In Gillis, K., Mével, C., Allan, J., et al., Proc. ODP, Init. Repts., 147: College Station, TX (Ocean Drilling Program), 45-108. 1993d. Site 895. In Gillis, K., Mével, C., Allan, J., et al., Proc. ODP, Init. Repts., 147: College Station, TX (Ocean Drilling Program), 109-159.

Teufel, L.W., 1983. Determination of in-situ stress from anelastic strain recovery measurements of oriented cores. In Kersch, K.M. (Ed.), Proc. 1983 SPE/DOE Joint Symp. on Low Permeability Gas Reservoirs: Denver, CO (Soc. Pet. Eng.), 421-430.

Zemanek, J., Caldwell, R.L., Glenn, E.E., Holcomb, S.V., Norton, L.J., and Strauss, A.J.D., 1970a. The borehole televiewer-a new logging concept for fracture location and other borehole inspection. J. Pet. Tech., 21:762774.

Zemanek, J., Glenn, E.E., Norton, L.J., and Caldwell, R.L., 1970b. Formation evaluation by inspection with the borehole televiewer. Geophysics, 35:254-269.

Zoback, M.D., Moos, D., Mastin, L., and Anderson, R.N., 1985. Well bore breakouts and in situ stress. J. Geophys. Res., 90:5523-5530.

Date of initial receipt: 3 August 1994

Date of acceptance: 11 March 1995

Ms 147SR-020 


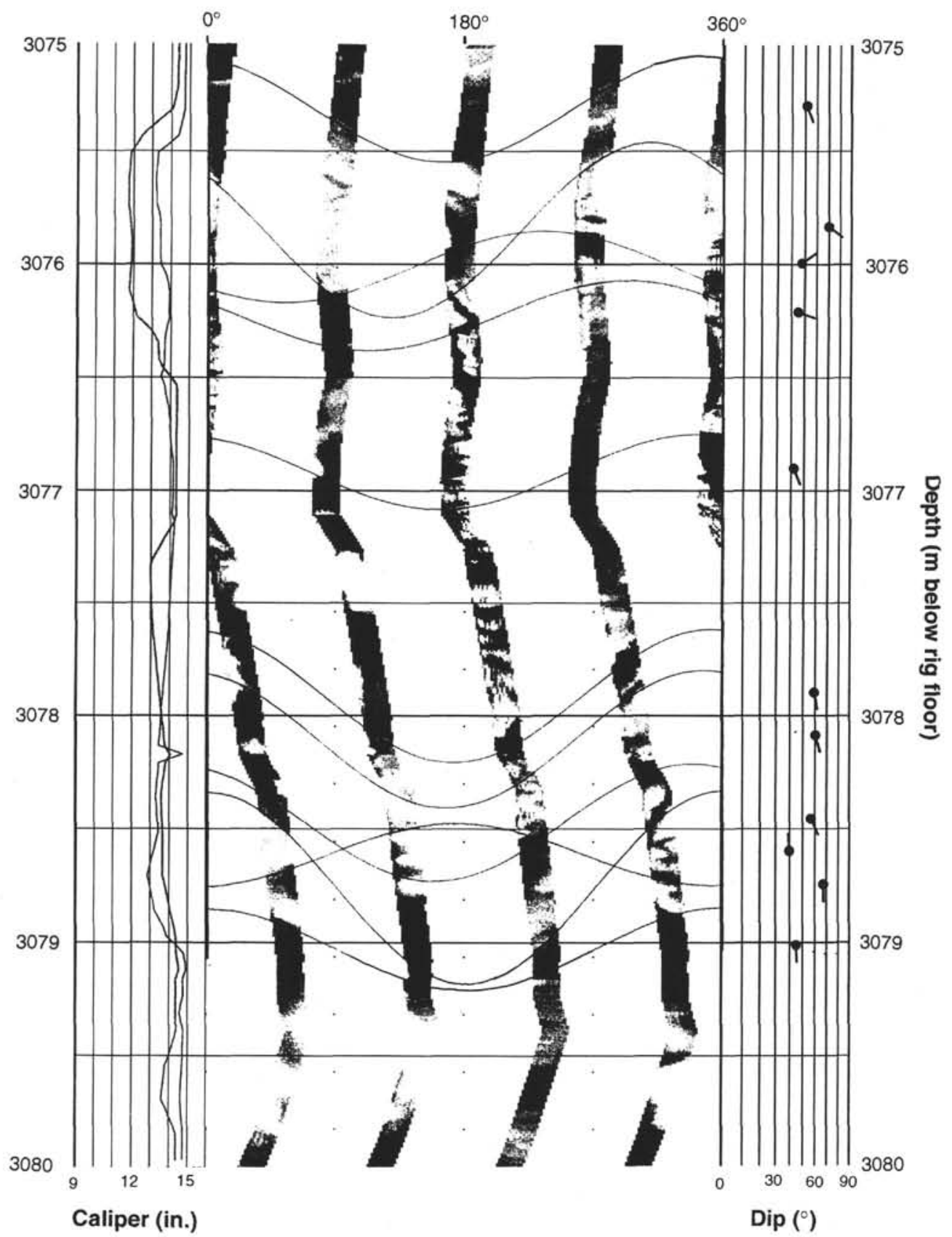

Figure 14. Example of a processed FMS image from Hole 894G (pass 2, 3075-3080 m below rig floor $=50-55$ mbsf). Low resistivities are shown as dark and high resistivities as light on a standard, unwrapped view of the inside of the borehole. Low-resistivity features are interpreted as open, water-filled fractures. Sinusoids fitted to several of the fractures show them to be approximately planar fractures with moderate dips $\left(40^{\circ}-70^{\circ}\right)$, mostly toward the south. Dips and dip directions are shown on the "dipmeter" plot at right, and the FMS calipers are displayed on the left-hand track. Azimuth is with respect to magnetic north. 
Table 5. FMS fracture picks.

\begin{tabular}{|c|c|c|c|c|}
\hline & Quality I & Quality 2 & Quality 3 & All together \\
\hline Visible on: & All 4 pads & 3-4 pads & $2-3$ pads & \\
\hline Plane orientation: & $\begin{array}{c}\text { No } \\
\text { ambiguity }\end{array}$ & $\begin{array}{l}\text { Well } \\
\text { constrained }\end{array}$ & $\begin{array}{c}\text { Some } \\
\text { ambiguity }\end{array}$ & \\
\hline $\begin{array}{l}\text { Number of picks: } \\
\text { Modal value of the poles: }\end{array}$ & 27 & 75 & 75 & 177 \\
\hline $\begin{array}{l}\text { azimuth } \\
\text { plunge }\end{array}$ & $\begin{array}{r}356.4 \\
30.1\end{array}$ & $\begin{array}{r}356.0 \\
31.9\end{array}$ & $\begin{array}{r}350.4 \\
54.6\end{array}$ & $\begin{array}{r}354.4 \\
39.7\end{array}$ \\
\hline
\end{tabular}
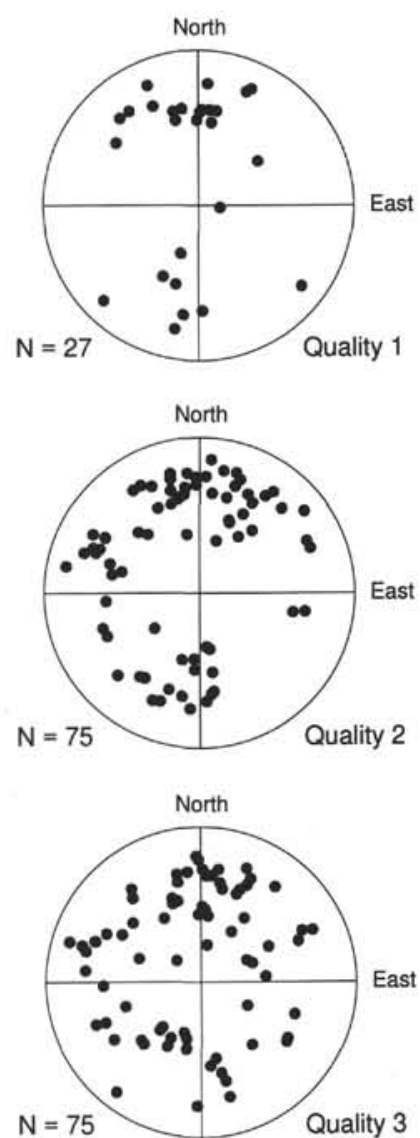

Figure 15. Equal-area lower hemisphere stereographic projections of poles to the planes of fractures identified on the FMS images of all five passes in the $45-80 \mathrm{mbsf}$ interval, subdivided by data quality. The azimuth is with respect to geographic north (after applying an $8^{\circ}$ declination correction). 


\section{A Veins in cores 45-80 mbsf}
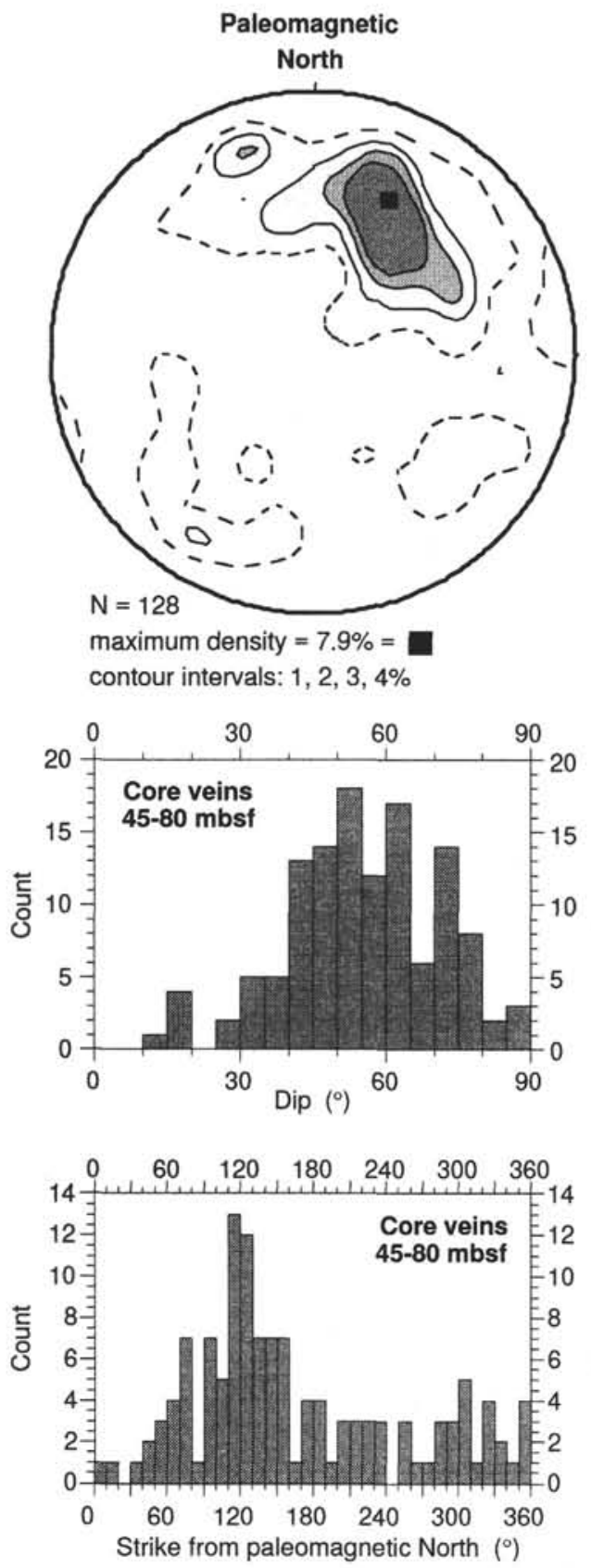

\section{B Fractures on FMS 45-80 mbsf}
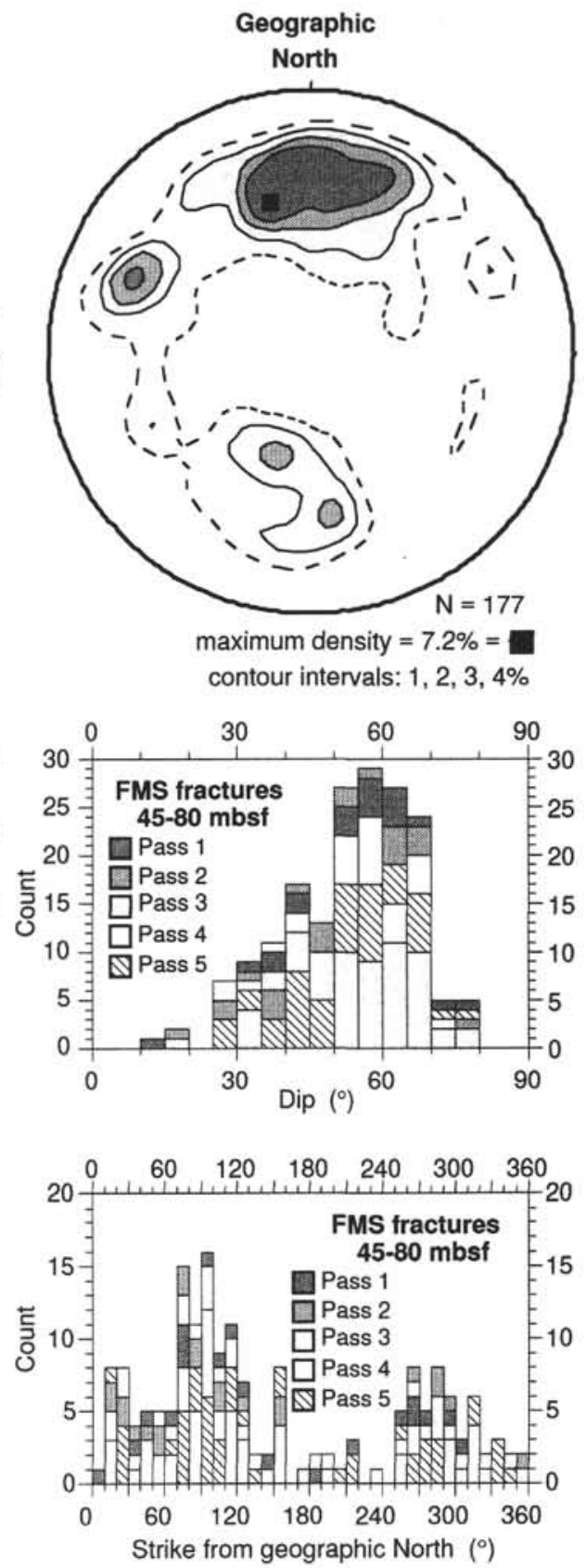

Figure 16. Fractures observed on FMS images and veins observed in cores in the logged interval of Hole 894G. The fracture orientations are plotted as (top to bottom) density contours of the fracture poles on a lower hemisphere equal-area stereographic projection, as histograms of fracture dips, and as histograms of fracture strikes. A. The veins are oriented relative to the paleomagnetic north. B. The fractures are oriented relative to the geographic north (after applying an $8^{\circ}$ declination correction). The five different histogram shadings correspond to the five different passes. Note on the FMS data the marked east-west preferred orientation, parallel to the trend of the Cocos-Nazca propagating rift, and near absence of north-south-trending brittle features that may have been created at the East Pacific Rise. Matching the core to FMS data implies that the core magnetization direction points north-northwest rather than north, and may reflect an early $30^{\circ}-40^{\circ}$ counterclockwise vertical-axis tectonic rotation of the gabbros of Hole 894G. 